\title{
Operative communication: project Cybersyn and the intersection of information design, interface design, and interaction design
}

\author{
Sebastian Vehlken ${ }^{1}$
}

Received: 16 June 2021 / Accepted: 15 October 2021 / Published online: 10 January 2022

(c) The Author(s) 2022

\begin{abstract}
This article examines the connecting lines between the Chilean Project Cybersyn's interface design, the German Hochschule für Gestaltung Ulm and its cybernetically inspired approaches towards information design, and later developments in interaction design and the emerging field of Human-Computer Interaction in the USA. In particular, it first examines how early works of designers Tomàs Maldonado and Gui Bonsiepe on operative communication, that is, language-independent (and thus internationalizable) pictogram systems and visual grammars for computational systems, were intertwined with attempts to ground industrial design in a scientific methodology, to address an era of computing machines, and to develop the concept of the interface as a heuristic for a renovated design thinking. It thereby also reconstructs further historical vanishing lines-e.g. the pictorial grammar of Otto Neurath's ISOTYPE—of the development of the 'ulm model' of design. Second, the article explores how an apprehension of first-order cybernetics in West Germany-e.g. represented by $h f g$ ulm staff like Max Bense or Abraham Moles, merged with Cybersyn's second-order cybernetics ideas, as represented by Stafford Beer's Viable System Model. And third, it asks about a further conceptual turn regarding an understanding of design which resulted in a focus on communicative interaction, e.g. in the later works of Fernando Flores and Terry Winograd on HCI, or in Beer's Team Syntegrity approach. As an effect, the text will explore a specific and international network of cybernetic thinking between Latin America, Europe, and North America which emerged around Project Cybersyn, and which was occupied with questions of $\mathrm{HCI}$, a democratization of design, and intelligence amplification.
\end{abstract}

Keywords Cybersyn · HFG Ulm · Design history $\cdot$ Information theory $\cdot$ Interface design · Interaction design

\section{Introduction}

There are few historical examples from the "age of cybernetics" (Pias 2004) that unfold such a far-reaching power of imagination as Project Cybersyn. From 1971-1973, and with the flamboyant British management consultant Stafford Beer as its director, Cybernetic Synergy (or, SYNCO in Spanish) was set up to develop an "Environment for Decision" with which Salvador Allende's administration desired to pave the way to democratic socialism for the Chilean economy and society. Cybersyn aimed to ground expert knowledge in dataguided policy making (Loeber 2018, p. 1). Its media a priori consisted of a combination of networked communication

Sebastian Vehlken

sebastian.vehlken@leuphana.de

1 MECS Institute for Advanced Studies on Media Cultures of Computer Simulation, Leuphana University Lüneburg, 21335 Lüneburg, Germany infrastructures, participatory elements and feedback channels, and innovative information design, held together by one of the most advanced cybernetic control doctrines of its time, Beer's biologically inspired Viable System Model.

The combination of the above elements, further amplified by the (retro-) futuristic interior of the system's Operations Room as its iconic representative (Fig. 1), seems to strongly resonate with current discourses: Some authors put to the fore a mere nostalgic perspective on a past techno-futures and alternative political imaginations, with some suggesting visions of a "post-work-society" or even a "fully automated luxury communism" à la Mason (2016) or Nick Srnicek (2016). Headlines read accordingly: Socialism meets Science Fiction, Chile's Cybernetic Dream of Justice, The Right Software for Socialism, or The Socialist Internet (see e.g. Beckett 2003; Barrionuevo 2008; Borchers 2018; Schmidt and Funk 2020; Athanasiou 1980). Others ponder the project's visionary in connection to current computational environments and their consequences: Project Cybersyn and the Origins 


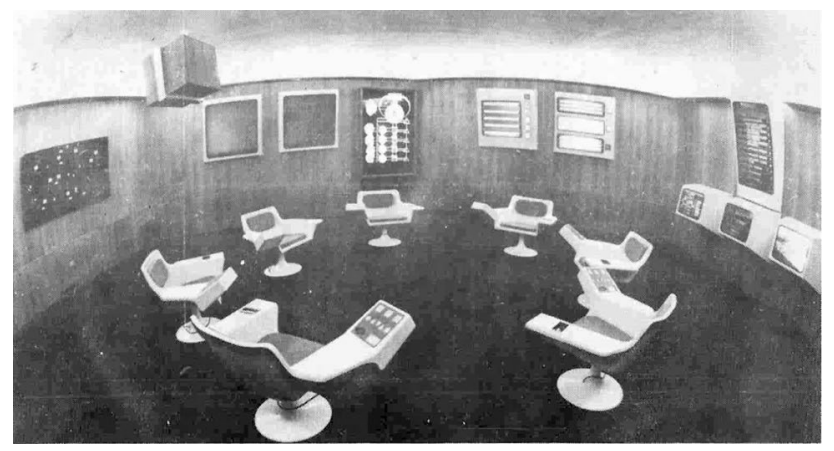

Fig. 1 Reprinted from: Grupo de Proyecto de Diseño Industrial INTEC/CORFO (1973) Diseño de una Sala de Operaciones. INTEC 4, 19-28: 19. With permission from the National Development Corporation Corfo

of the Big Data Nation, The Origins of Algorithmic Life, The State as Machine, or A Tech-State Dream (see e.g. Rivière 2010; Morozov 2014; Axelrod and Borenstein 2009). And again others criticize some neoliberal aspects inherent in Cybersyn's alleged lean government approach, putting it in line with recent ideas of "smart states" (Noveck 2015) or the "Info-State" (Khanna 2017). Not least, Eden Medina, the historian of technology who pioneered research into this unlikely endeavor towards a democratic cybernetic state with her seminal book Cybernetic Revolutionaries (2011), discussed the significance of Cybersyn for a contemporary handling of computing technology and data (Medina 2015).

Repeatedly, authors have devoted special attention to the Operations Room and its interface elements, which have often been marked as harbingers of Human-Computer Interaction (HCI) concepts and technologies to come. Medina (2011) offers a thorough historical analysis of this 'liberty machine's' development and international linkages, as well as past-Cybersyn careers of key project members. Also, former team members like Cybersyn's design director Gui Bonsiepe or the industrial engineer and Cybersyn director Raùl Espejo have published numerous publications on the Opsroom design philosophy and process. Although Medina (2011) touches on the Opsroom's design history and legacy, a detailed inquiry in its genealogy and its role for 'design thinking' is still pending. Thus, in the following, this article will offer a twofold perspective: With the Opsroom as sort of a connecting node, it associates early info-graphic concepts in Otto Neurath's ISOTYPE language with design theories developed by Tomàs Maldonado and Bonsiepe at German Design School $h f g \mathrm{ulm}$, as well as with Beer's later Team Syntegrity methodology and Fernando Flores' and Terry Winograd's seminal HCI writings. The article thus charts an interplay of elements from information design, interface design and interaction design which revolve around the media- and techno-history of the Opsroom. Furthermore, it will examine how Cybersyn thereby needed to synthesized two cybernetic perspectives: Whilst Beer catered the project with approaches from British management cybernetics that were built around his second-order-cybernetics concept of the Viable System Model (VSM), Bonsiepe contributed approaches of 'operative communication' which had taken inspirations e.g. from first-order cyberneticians such as Max Bense and Abraham Moles, or from the neopositivist Unity of Science movement. As an effect, Cybersyn connects different understandings towards design in the presence of computing media. But whether information, interface or interaction design, these conceptions were all related to a participatory 'reprogramming' towards societal change. And this particular mindset is a key factor for the project's relevance in our information-technologically interwoven present.

\section{Information design I: hfg uIm}

In the turbulent year of 1968, when the German Arts and Design College hfg ulm was closed after years of political debate and refutation, the designer Gui Bonsiepe suddenly found himself without a job. hfg ulm-with its lower case title indeed serving as a clear indicator of its aesthetical and conceptual Bauhaus heritage — certainly was the most influential design school in post-WWII West Germany. Primarily, its international reputation is based on its minimalist aesthetics, its attempts to integrate design in industrial processes, and its advancement of the transdisciplinary methodologies of the Bauhaus towards new levels: The ulmer modell of design education sought to strongly connect visual design aspects with science and technology by including disciplines like cybernetics, semiotics, operations research, semiotics, analytical philosophy or Gestalt psychology into the curriculum. But its avantgardist and theory-laden design concepts increasingly estranged the school from the WestGerman mainstream already during the 1960s. And explicitly anti-capitalist activities in the second half of the decade provided further political munition for cutting the school's funds. This latter aspect aggravated the situation of former employees. Bonsiepe recalls that "the closing of the hfg, however, was due less to worries over its academic qualities than to motives of a retaliatory adverse faction, which saw to it that none of the hfg's permanent instructors were [sic!] hired by any of the institutions founded after its closing-a McCarthy-like campaign known as Berufsverbote [professional ban or blacklist] that started as a reaction against the political unrest [...]" (Bonsiepe 1995, p. 11).

Amidst this tense political climate, and following working experience in Argentina in 1964 and 1966, Bonsiepe's new working environment initially became the Chilean State Development Organization. From 1970 onwards, he also started teaching industrial design at the Catholic 
University's School of Engineering, later extending this role into the School of Communication - a move which seems to reflect Bonsiepe's transdisciplinary routines from $h f g \mathrm{ulm}$. In that year, he also made the acquaintance of Fernando Flores, then director of the university's engineering school, who had been captivated by Bonsiepe's interest for Operations Research and cybernetics: If a designer had a Stafford Beer volume on his bookshelf, the profession had to have something in it, Flores allegedly stated (Medina 2011, p. 211). Whether it was for findings like this or not, in any case Flores forced the creation of an industrial design group at the State Technology Institute (INTEC) after Allende came to power, with Bonsiepe as its leader. At the same time, having been sensitized for the mere political dimensions of design already during his mid-60s engagements in South America, Bonsiepe now put much attention to the development of a design philosophy dedicated to social change (Bonsiepe 1974). And as an effect, it suddenly appears quite consistent that a blacklisted West-German designer found itself at the head of the design team that created the Operations Room of a South-American 'cybernetic socialism' project, whose mastermind, respectively, was a British Management Consultant. The Cybersyn Opsroom, as Medina observes,

"did incorporate elements characteristic of the Ulm School of design [...]. The designers paid great attention to ergonomics and concerned themselves with such questions as the best angles for a user to read a display screen. They studied aspects of information visualization and wondered how they could use color, size, and movement to increase comprehension or how much text could be displayed on a screen while maintaining legibility" (Medina 2011, pp. 114-115).

But which more exact genealogical traces can be identified that had been funneled into Cybersyn's opsroom by the hfg ulm connection? As mentioned above, Bonsiepe's activities in Chile reflect several facets of the hfg ulm methodology and working practice which first were introduced to him while still being a student there. In 1958, and after fierce internal controversy, the designer and founding director Max Bill left the school and made way for a rectorate with Otl Aicher, Hans Gugelot and the Argentinean designer Tomás Maldonado. Bill's primacy of the artistic in product design was abandoned: "The aesthetic factor is only one factor among many with which the product designer works. It is neither the most important nor the dominant one. Alongside it, there are the productive, constructive, economic and perhaps also the symbolic factors. Product design is not art, and the product designer is not necessarily an artist" (Maldonado 1958, p. 31).

The designer was now seen as the coordinator of this factor, which he had to transform into a product. The product, on the one hand, had to ensure maximum productivity for the manufacturer. On the other, however, it had to provide "maximum material and cultural" satisfaction for the consumer (Maldonado 1958, p. 34, cf. Rinker 2003, p. 41). The aesthetic value of a product shifted from a fixation on exchange value to its use value - and this can only be determined within a complex, transdisciplinary methodological matrix. The complex relationship between these values-as described, for example, by Karl Marx, Adam Smith, and John Maynard Keynes-would later receive more theoretical attention in Bonsiepe's writings from South America (Bonsiepe 1974). But first of all, for a product designer understood as a coordinator, the necessity followed.

"in addition to planning and design skills, to have scientific knowledge in the fields of economics, psychology and production technology. Thus, the product designer should inform himself about the theories of demand and consumption. [...] Also, in order to define the factors for increasing productivity, the product designer should familiarize himself with the planning and process research from the 'operational research', and the laws of 'automation'. [...] Far ahead of his time, Maldonado recognized the phenomenon of miniaturization and automation as a result of the microelectronic revolution"” (Rinker 2003, p. 42).

The new educational concept, the ulmer modell, was decisively shaped by Tomàs Maldonado, and co-developed by apologists of the information age such as Max Bense, Abraham A. Moles, and Horst Rittel. It attempted to shift the focus of industrial design and its potentially progressive horizon from the confection of individual consumer products to the design of communications systems and the organization of collaborative, project-based engineering. This turn away from modernist ideas of 'good form' in Bill's sense, as Swiss sociologist and design theorist Lucius Burckhard observed, explicitly reflected the fact that in the case of new information machines "more and more artefacts structurally eluded any attempt to reconcile their visible form und their technical function." It now was their invisible organization which determined their function which was "conveyed to the user solely via external control elements: '[If we don't know these buttons [...], if they don't tell us anything, then this apparatus remains alien and useless to us" (Burckhardt 1967, p. 43, cf. Meyer 2019, p. 239). Therefore, the ulmer modell combined practical design education with intensive theorizing. Guest lecturers such as Norbert Wiener and R. Buckminster Fuller were regular visitors, and Otto Neurath and other members of the Unity of Science movement brought in neopositivist ideas of the Vienna Circle.

Also, and quite unusual for design schools at the time, a Department for Information under the direction of Max Bense was founded. In Ulm, workshops with writers such as Hans Magnus Enzensberger were combined with courses 
on language analysis and semiotics. Bense related semiotics-based on its foundations in Charles Sanders Peirce and Charles Morris - to ergonomic and information-theoretical questions and argued for a 'mathematical semiotics': The formation of signs in human consciousness and their processing was understood ultimately as about the exclusion of interference: "[T]he triadic sign model (M,O,I) and the transmitter-channel-receiver model of Shannon-Weaver's information theory he sees-despite all obvious disparity, as Eco has aptly elaborated-a deep kinship, as well as between Peirce's 'dynamic interpreter' and its infinite iterability with the so-called cybernetic loop, the 'cyclic causality' of feedback" (Mersch 2018, p. 75).

In his introduction to information-theoretical aesthetics (Bense 1956, 1965), Bense thus pursues, quite similarly to Moles in his Information Theory and Esthetic Perception (1968), the question of an 'objective aesthetics,' of a universal theory of sign use in the technical world (Herrmann 2018 , p. 89). Terms such as the information measure are explained and diagrams are presented "that indicate, for example, the structural complexity of a playing card or a moon rocket in relation to its functional complexity" (Mäntele 2003, p. 84).

"This is done at the price of a formalization that models the perceptible, as the ground or outcome of the aesthetic, as a discretizable and thus well-differentiated series from which the practice of design draws in the first place. Each event has the form $E=\left(E_{1}, . ., E_{n}\right)$, the selection of which denotes the actual creativity, which can then be automated accordingly. It presupposes a decomposable series already. Art thus forms a decision process and the aesthetic a decision-logical series that can be traced back to a number of choice alternatives whose correlates are those mathematical algorithms as they can be operationalized by stochastic functions." (Mersch 2018, p. 78)

This impedes a kind of de-spiritualization of design activities through a Metatechnique of a Machine that is both programmatically proposed and programmatically proceeding (Bense 1951). However, to avoid reductionist and "conservative" outputs, Bonsiepe underscored the applied perspective which makes worthy such approaches: "Beauty is not immanent in mathematics, but this does not mean that it cannot be codified by mathematical processes. The heuristic value of mathematics for creative design clearly exceeds the epistemological value" (Bonsiepe 1968). And the focus was thereby directed to the operationality (and operationalizability) of communication. Subsequently, the Department of Visual Design, renamed Visual Communication in 1956 after a similarly oriented department at the New Bauhaus in Chicago, was concerned, for example, with the development of graphic design beyond advertising contexts. The focus was on the development and implementation of non-persuasive visual messages. In close cooperation with the Department of Information, the focus was on the planning and analysis of modern communication media. These included, for example, sign systems for road traffic, display devices on machines, or the visual implementation of scientific facts. Such areas "had not been taught systematically at any European school until then" (Rinker 2003, p. 46), and at Ulm, as Bonsiepe notes, were termed "operative communication" (Bonsiepe 2004).

Horst Rittel, with a design concept of 'planning action' in mind, meanwhile devoted himself to the subject of Operational Research, that "discipline developed in the USA, [which] consists of a spectrum of different subjects [which] have the goal of classifying, interpreting and evaluating operations of any kind in a mathematical way" (Maldonado 1958, cf. Mäntele 2003, p. 84). The consideration of elements like group theory, set theory, probability theory, statistics, game theory or linear programming were employed to make design processes more controllable. In this context, the systematic handling of variety was of special importance: Against a one-dimensional and linear understanding of problem comprehension, information and problem solution, Rittel placed an iterative process of repeated decompositions and syntheses of alternative designs. Because problem formulation goes hand in hand with the development of a proposed solution, information can only be meaningfully gathered under the premise of a solution principle, and a solution principle can only be developed to the extent that one is informed about the problem (Rittel 1970, p. 17).

Last but not least, cybernetics also acquires a great importance in the theory building of hfg ulm. Its scope is illustrated by the syllabus of a seminar offered by the cyberneticist Helmar Frank in the early 1960s:

"Concept and classification of cybernetics-The stages of objectification according to H. SchmidtDiscussion of cybernetic terminology according to Couffignal-Coding theory in redundancy-saving procedures-Drawing up flow diagrams, explained by the example of mean information and transinformation [...]-Basic facts and models of information psychology-Cybernetic pedagogy and teaching machines. 2nd quarter (technical and biological cybernetics): circuit algebra-structure of digital computing machines-automatic character recognition-models of learning (maze models, learning matrix...) - simplest elements of control engineering-logical neuron networks. 3rd quarter (information science): writing as coding of language, sound and character statistics, possibilities of speech syn- 
thesis-Mandelbrot's theory of language-Special questions of information aesthetics-Normative logic and rhetorical combination-Sociotechnology_Philosophy of cybernetics" (Frank 1963, cf. Mäntele 2003, p. 86).

For Gui Bonsiepe, the comprehensive theoretical education rather directly connected to practical projects in the field of interface design. Together with Tomàs Maldonado, he worked for the Italian computer company Olivetti on a drawing system for electronic data-processing equipment in 1960/61 (Bonsiepe and Maldonado 1963, p. 20). Ettore Sottsass, then an industrial designer at Olivetti, recognized the inadequate interface design of conventional computers and suggested a redesign of the display and display elements for the Olivetti computer ELEA 9003.

"The operator usually intervenes in the largely automatic work processes of the system by entering information via the keyboard, primarily for the purposes of control and correction. In addition to the control panel, individual devices $[\ldots .$.$] have small fields with keys and$ lamps. In all electronic data processing equipment currently available on the market, the multitude of lights and keys are identified by words and/or abbreviations. This form of symbolization has some weaknesses in terms of learnability, recognizability and protection against misinterpretation, apart from the fact that it is not suitable for international use" (Bonsiepe and Maldonado 1963, p. 20).

To address these weaknesses, Bonsiepe and Maldonado developed a non-phonogrammatical sign system. For this purpose, they recorded and analyzed about twenty different already existing sign systems from fields such as "cartography, meteorology, typography, circuitry, alchemy [sic!], and music" (Bonsiepe and Maldonado 1963, p. 21). The objective was to identify associative constants in this way (Fig. 2).

From their inventory of signs they synthesized an inventory or 'alphabet', consisting of two classes of signs: First, the basic signs, "comparable to nouns"; second, the determinatives, "comparable to the adjectives and verbs of a language" (Bonsiepe and Maldonado 1963, p. 21). The basic symbols referred to the hardware elements, the functional units of the computer system, such as "magnet tape, paper tape recorder, drum memory" (Bonsiepe and Maldonado 1963, p. 21). Their symbols were based on the basic geometric shape of the square, therefore, possess a planar character. The determinatives primarily denoted states and operations of the computer, and their symbols have a linear character. Both classes of signs are connected to each other by syntactic and semantic relations: "The character for 'write' is integrated into the character for 'punch card recorder'. The character for 'read' is the inverse of 'write'. In order not to impair recognizability, no more than a maximum of three characters were combined with each other" (Bonsiepe and Maldonado 1963, p. 21). In sum, they created a visual grammar which "preconfigured the contemporary use of icons in computer interfaces" (Mori 2020).

Bonsiepe thus traveled to Chile in October 1968 as a "proven expert in industrial design" and graphic design (Fernández 2003, p. 121). He and other former 'Ulmers' who accompanied him brought with them a comprehensive design education based on OR and cybernetics to South America. Economic considerations, interdisciplinarity, familiarity with cybernetics, experimental work-these elements of the training at the $h f g u l m$ can be found again in the requirements of the Cybersyn project. In Ulm, so to speak, there already was a conglomerate of those structural specifications under which a handful of $h f g$ graduates in Chile some years later designed the visual grammar of the Opsroom (Bonsiepe 1974, p. 207). Before the article turns to its interface design, however, a second and historically more far-reaching genealogical vanishing line should be pointed out.

\section{Information design II: ISOTYPE}

The international visual language ISOTYPE by the Austrian social philosopher and economist Otto Neurath had not explicitly been taken up by the design methodologies later developed at $h f g$ ulm or even in Chile. Neurath's influence on education in Ulm seems to have been limited to his philosophical ideas. However, in terms of the communicative objectives of visual representations, his suggestions seem like a harbinger of some key viewpoints that can be found in a similar form in the visual grammars as implemented at $h f g$ and in the context of Cybersyn.

From 1925 onwards, Neurath worked at the Vienna Museum of Society and Economy, whose founding he himself had initiated (see Kinross 1991, p. 9). It was meant to be a "people's institute for social enlightenment" (Hartmann 1997). Here, he developed his revolutionary communicativetheoretical and media-pedagogical approach of a return to the iconic, to make social conditions visible and understandable for all strata of the population and thus to put them at the service of social change (Hartmann 1997): "Modern man is first and foremost a man of the eyes. [...] Even those who read many books draw more and more stimulation from pictures and picture series. The tired person quickly takes note of something that he could no longer grasp by reading. [...] Words separate, pictures connect" (Neurath 1991a, pp. 189-190).

For Neurath, the 'maximization of happiness' for the individuals of a society is at the center of his work. Even as a later consultant for the rehabilitation of British slums 


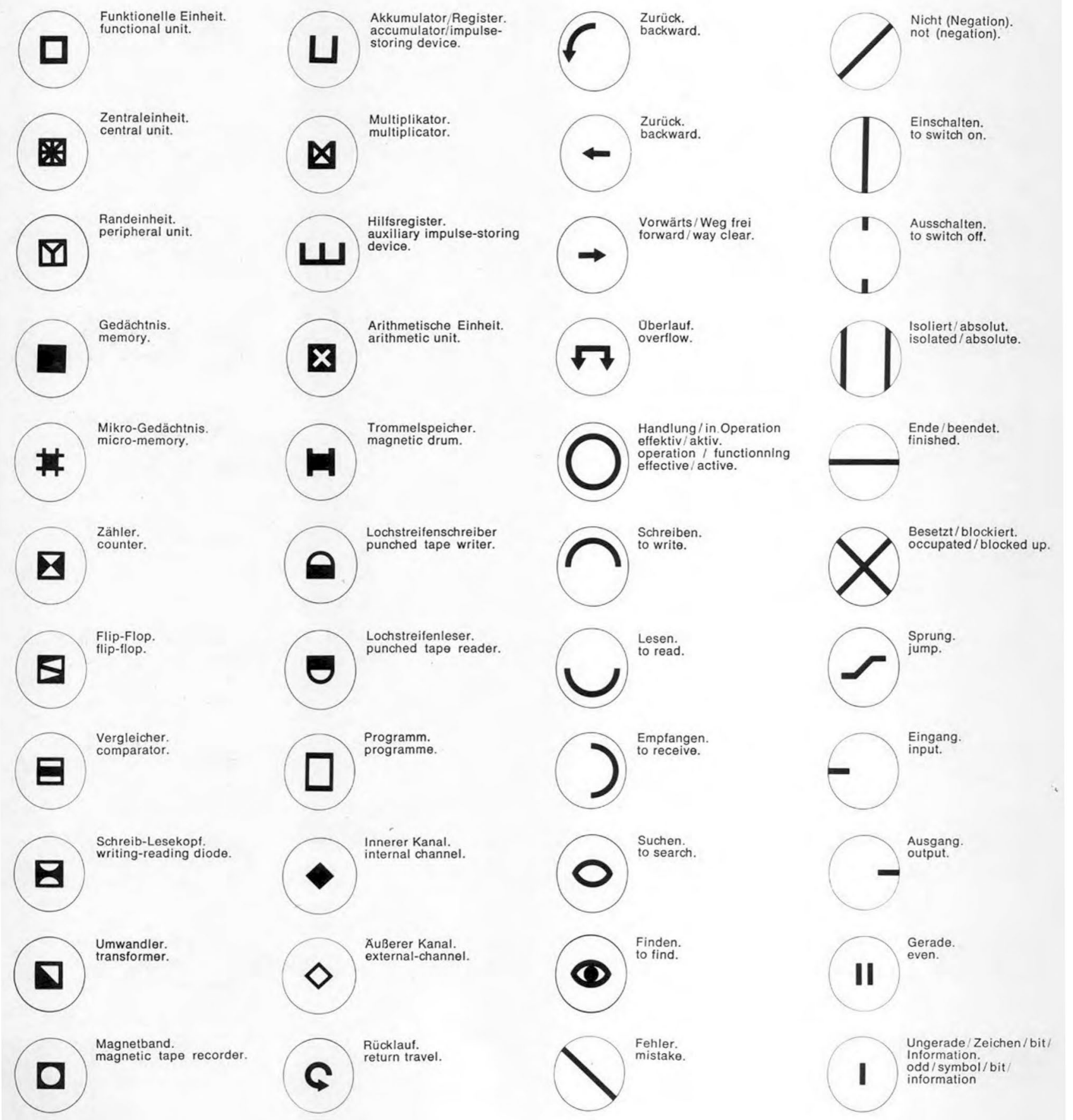

Fig. 2 Reprinted from: Bonsiepe G, Maldonado T (1963) Zeichensystem für elektronische datenverarbeitende Anlagen (1960/61). ulmZeitschrift der Hochschule für Gestaltung 8/9: 20-24. With permission from HfG Ulm Archive and Gui Bonsiepe

in 1941 he gave himself the title 'Consulting Sociologist of Human Happiness' (Hartmann 2002, p. 23). Just like Stafford Beer, Neurath conceived of the living conditions of a society as being manageable. As a social reformer, his addressees were the working proletariat, i.e., people who were neither literate nor educated to the extent that they had the leisure time to think creatively and improve their situation with the help of sophisticated reading. By using intuitively understandable images and signs, he attempted to "form tools of thought for everyday life" (Hartmann 2002, p. 24). 


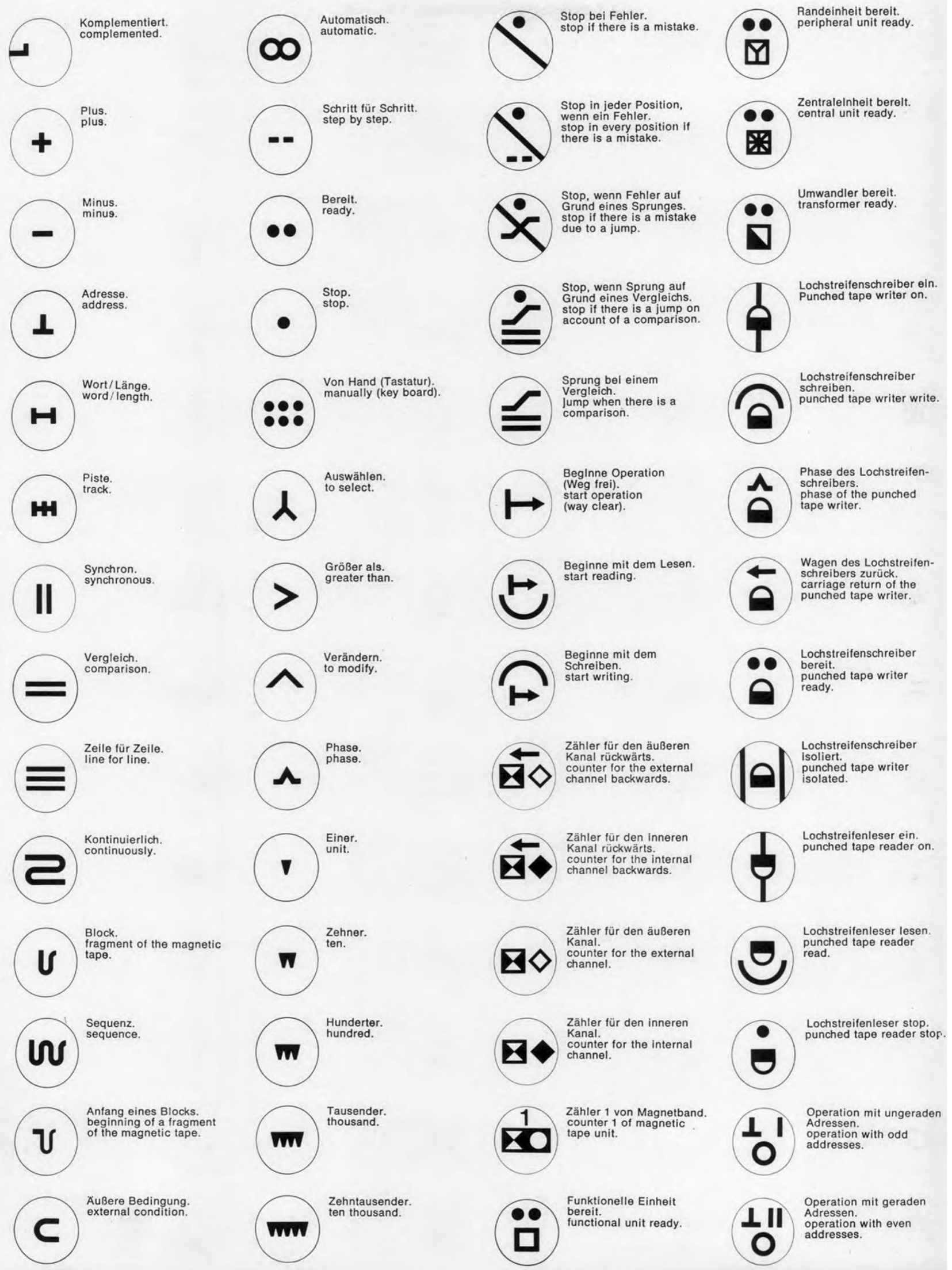

Fig. 2 (continued) 


\begin{tabular}{|c|c|c|c|}
\hline $\begin{array}{l}\text { Auberer Kanal arbeitet } \\
\text { mit ungeraden Adressen. } \\
\text { external channel operates } \\
\text { with odd addresses. }\end{array}$ & $\begin{array}{l}\text { Ende des Magnetbandes. } \\
\text { end of magnetic tape. }\end{array}$ & $\begin{array}{l}\text { Schreiben in Gedächtnis } \\
\text { mü. } \\
\text { writing into memory mu. }\end{array}$ & $\begin{array}{l}\text { Das Zeichen ist gefunden. } \\
\text { the symbol has been } \\
\text { found. }\end{array}$ \\
\hline $\begin{array}{l}\text { Außerer Kanal arbeitet } \\
\text { mit geraden Adressen. } \\
\text { external channel operates } \\
\text { with even addresses. }\end{array}$ & $\begin{array}{l}\text { Ende des Lochstreifen- } \\
\text { schreibers. } \\
\text { end of the punched } \\
\text { tape writer. }\end{array}$ & $\begin{array}{l}\text { Akkumulator arbeitet. } \\
\text { accumulator in operation }\end{array}$ & $\begin{array}{l}\text { Block für Block. } \\
\text { fragment for fragment. }\end{array}$ \\
\hline $\begin{array}{l}\text { Innerer Kanal arbeitet mit } \\
\text { ungeraden Adressen. } \\
\text { internal channel operates } \\
\text { with odd addresses. }\end{array}$ & $\begin{array}{l}\text { Ende Akkumulator } \mathrm{T} \text {. } \\
\text { end of the accumulator } \mathrm{T} \text {. }\end{array}$ & $\begin{array}{l}\text { Im Akkumulator ist ein } \\
\text { Zeichen. } \\
\text { the accumulator contains } \\
\text { a symbol. }\end{array}$ & $\begin{array}{l}\text { Schreib-Lesekopf ein. } \\
\text { writing-reading diode on. }\end{array}$ \\
\hline $\begin{array}{l}\text { Innerer Kanal arbeitet mit } \\
\text { geraden Adressen. } \\
\text { internal channel operates } \\
\text { with even addresses. }\end{array}$ & $\begin{array}{l}\text { Ende des Multiplikators. } \\
\text { end of the multiplicator. }\end{array}$ & $\begin{array}{l}\text { Inhalt des Akkumulators } \\
\text { ist minus. } \\
\text { content of the accumula- } \\
\text { tor is minus. }\end{array}$ & $\begin{array}{l}\text { Trommelspeicher ein. } \\
\text { magnetic drum on. }\end{array}$ \\
\hline $\begin{array}{l}\text { Adressen sind gleich. } \\
\text { addresses are the same. }\end{array}$ & $\begin{array}{l}\text { Ende der Suche. } \\
\text { end of search. }\end{array}$ & $\begin{array}{l}\text { Inhalt des Akkumulators } \\
\text { ist Null. } \\
\text { content of the accumu- } \\
\text { lator is zero. }\end{array}$ & $\begin{array}{l}\text { Programm 1, } 2,3 \text { stop. } \\
\text { programme } 1,2,3 \text { stop. }\end{array}$ \\
\hline $\begin{array}{l}\text { Synchronismus beim } \\
\text { Lesen. } \\
\text { synchronism during the } \\
\text { reading operation. }\end{array}$ & $\begin{array}{l}\text { Ende der Information. } \\
\text { end of the information. }\end{array}$ & $\begin{array}{l}\text { Oberlaut } T \text {. } \\
\text { overflow } T \text {. }\end{array}$ & $\begin{array}{l}\text { Phase des zweiten Pro- } \\
\text { gramms. } \\
\text { phase of the second } \\
\text { programme. }\end{array}$ \\
\hline $\begin{array}{l}\text { Synchronismus von } \\
\text { Gedächtnis mü. } \\
\text { synchronism of memory } \\
\text { mu. }\end{array}$ & $\begin{array}{l}\text { Ende des Schreibens auf } \\
\text { Magnetband. } \\
\text { end of writing on } \\
\text { magnetic tape. }\end{array}$ & $\begin{array}{l}\text { Im Multiplikator ist ein } \\
\text { Zeichen. } \\
\text { the multiplicator con- } \\
\text { tains a symbol. }\end{array}$ & $\begin{array}{l}\text { Magnetband Gedächtnis } \\
\text { rho bereit. } \\
\text { magnetic tape of memory } \\
\text { rho ready. }\end{array}$ \\
\hline $\begin{array}{l}\text { Schreiben eines Ver- } \\
\text { gleichs. } \\
\text { writing of a comparison. }\end{array}$ & $\begin{array}{l}\text { Ende des Lesens vom } \\
\text { Magnetband. } \\
\text { end of reading of } \\
\text { magnetic tape. }\end{array}$ & $\begin{array}{l}\text { Bit } a, b, c, d \text { des } \\
\text { Multiplikators. } \\
\text { bit } a, b, c \text {, } d \text {, of the } \\
\text { multiplicator. }\end{array}$ & $\begin{array}{l}\text { Gedächtnis mü chi } \\
\text { Werte } 1 \text { bis } 7 \text {. } \\
\text { memory mul value } \\
1 \text { up to } 7 \text {. }\end{array}$ \\
\hline $\begin{array}{l}\text { Vergleich von Gedächtnis } \\
\text { chi. } \\
\text { comparison of memory } \\
\text { chl. }\end{array}$ & $\begin{array}{l}\text { Ende des Schreibens } \\
\text { eines Blocks. } \\
\text { end of writing of a } \\
\text { fragment. }\end{array}$ & $\begin{array}{l}\text { Register }, \text { J J M, N, O, P. } \\
Q, R, S \text { fur Adressen. } \\
\text { register H, J, M, N, O, P. } \\
Q, R, S \text { for addresses. }\end{array}$ & $\begin{array}{l}\text { Input bit } a, b, c, d, e, t, \\
k \text { in Gedähthis mü. } \\
\text { input bit a, } b \text {, c. } d, e, f \text {. } \\
k \text { in memory mu. }\end{array}$ \\
\hline $\begin{array}{l}\text { Zeichen geht vom } \\
\text { Gedächtnis zur } \\
\text { arithmetischen Einheit. } \\
\text { symbol is going from } \\
\text { memory to arithmetic } \\
\text { unit. }\end{array}$ & $\begin{array}{l}\text { Anfang einer Sequenz. } \\
\text { beginning of a sequence. }\end{array}$ & $\begin{array}{l}\text { Operation 'stop'. } \\
\text { operation 'stop': }\end{array}$ & $\begin{array}{l}\text { Output bit a, b, c, } d, e, f \text {, } \\
k \text { von Gedachtnis mu. } \\
\text { output bit a, } b, c, d, e, f \text {. } \\
k \text { of memory mu. }\end{array}$ \\
\hline $\begin{array}{l}\text { Verbindung von zwei } \\
\text { Magnetbändern über } \\
\text { einen Adressengeber. } \\
\text { connection of two } \\
\text { magnetic tape units via } \\
\text { an addressing unit. }\end{array}$ & $\begin{array}{l}\text { Ende der Sequenz. } \\
\text { end of the sequence. }\end{array}$ & $\begin{array}{l}\text { Handeingabe (Tastatur) } \\
\text { stop. } \\
\text { manual input (key board) } \\
\text { stop. }\end{array}$ & $\begin{array}{l}\text { Innerer Kanal, Einer, bit } \\
\text { a, b, c, d, e, f. } \\
\text { internal channel unit, bit } \\
\text { a, b, c, d, e, f. }\end{array}$ \\
\hline $\begin{array}{l}\text { Ende der Operation. } \\
\text { end of operation. }\end{array}$ & $\begin{array}{l}\text { Bit theta wird gelesen. } \\
\text { bit theta is read. }\end{array}$ & $\begin{array}{l}\text { Magnetband stop. } \\
\text { magnetic tape unit stop. }\end{array}$ & $\begin{array}{l}\text { Außerer Kanal, Einer, } \\
\text { bit a, b, c, d, e, f. } \\
\text { external channel, unit, } \\
\text { bit } a, b, c, d, e, t \text {. }\end{array}$ \\
\hline $\begin{array}{l}\text { Ende der arithmetischen } \\
\text { Operation. } \\
\text { end of the arithmetic } \\
\text { operation. }\end{array}$ & $\begin{array}{l}\text { Ein Zeichen wird gelesen. } \\
\text { a symbol is being read. }\end{array}$ & $\begin{array}{l}\text { Magnetband besetzt. } \\
\text { magnetic tape unit } \\
\text { occupied. }\end{array}$ & $\begin{array}{l}\text { Innerer Kanal, Ausgang, } \\
\text { bit a, b, c, d, e, f. } \\
\text { internal channel, output, } \\
\text { bit a, b, c, d, e, f }\end{array}$ \\
\hline $\begin{array}{l}\text { Ende des Vergleichers. } \\
\text { end of the comparator. }\end{array}$ & $\begin{array}{l}\text { Auswahl beim Lesen. } \\
\text { selection during reading. }\end{array}$ & $\begin{array}{l}\text { Flip-Flop lambda mü. } \\
\text { flip-flop lambda mu. }\end{array}$ & 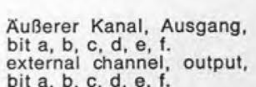 \\
\hline
\end{tabular}

Fig. 2 (continued) 
Neurath linked the development of his visual language to the "development of the modern technique of living together" (Hartmann 2002, p. 27), a technique that was expressed in social and economic statistics. Their pictorial mode of presentation should make them generally and, above all, quickly comprehensible: "Remembering simplified pictures of people is better than forgetting exact figures" (Hartmann 2002, p. 29; Neurath and Nemeth 1994, p. 68). It must be kept in mind that, unlike today, no standardized repertoires of iconic signs existed at that time. In the 1920s, pictograms were not media-technical realities, but objects to be designed and produced first.

Two aspects are significant in this process: The first is the transformation of statistical data into pictorial information, taking into account the selection of the information to be depicted and its reduction to the essentials (Fig. 3).

Transformation meant nothing less than variety processing, variety engineering, reduction of complexity - with a side effect not to be underestimated, which is inherent in any graphical user interface: Namely, "that everyone understands what he sees, means conversely only that what cannot be seen can never be understood" (Pias 2002, p. 138). The second aspect was the formation of a coherent visual code (Hartmann 2002, p. 48). To this end, several rules soon crystallized: First, pictorial signs were used relationally. Quantities were therefore not represented as larger lines, but by the repetition of the original sign (Fig. 4).

Second, preferred typified signs with the highest possible iconicity were used, which consist entirely of elements absolutely necessary for recognition and did not have an illustrative character-signifier and signified were to be brought into congruence as far as possible. Third, the consistency of the pictorial signs was essential, i.e. the use of the same sign for the same content without creative embellishment, which should guarantee their recognizability and immediacy. Fourth, the signs should be self-explanatory so that additional texts were not necessary (Figs. 5, 6).

And fifth, the clarity of the color scheme was important to accentuate differences or to group signs (see Hartmann 2002, p. 63, Hartmann 2000, pp. 159-160). Interestingly, several works on visual communication from Bonsiepe's time at INTEC show astonishing similarities to Neurath's methods of depiction (see Bonsiepe 1974, p. 179). Neurath used display panels as a medium for conveying information-usually large, colored, square murals with a side length of $126 \mathrm{~cm}$ (see Kinross 1991, p. 10). They are set up in museums and rooms of public institutions (see Kinross 1991, p. 10) and show graphic representations of social facts and contexts, from migration movements to social housing to infant mortality, based on the pictogram reservoir of ISOTYPE. The images displayed on such a panel follow a triad of vision that is meant to guarantee instantaneous comprehension in the literal sense of the word:
"A picture made according to the rules of the Viennese method shows at first glance what is most important about the object; obvious differences must immediately catch the eye. At second glance, it should be possible to see the more important details, and at third glance, what other details there may be. A picture that gives even more information at the fourth and fifth glance is, from the point of view of the Vienna School, to be discarded as pedagogically unsuitable" (Neurath 1991b, p. 257).

In summary, the following conceptual parallels between Neurath's pictogram and display board design and Bonsiepe's later Opsroom interface design can be noted: The interface elements were designed in a uniform and standardized manner and were thus quickly comprehensible. They were presented as large-scale wall displays, which supported collaborative use. Quantities were represented relationally, numbers were not or hardly used. Access barriers were kept low-working-class participation was an important goal in each case-and science was put at the service of the people. And what is more: The design was done in the firm belief that the scientific methods applied could improve social conditions.

\section{Cybersyn: interface design}

After all, the meeting of a design approach which was influenced by information, and of cybernetic management theory implemented on the state level might seem both coincidental and logical. But Cybersyn involved a conceptual leap that assigns the approaches of an 'objective information aesthetics' imported from Ulm a specific place in an expanded understanding of cybernetic communication and control. In contrast to their abstract foundation in (mathematical) signs, language systems, and (visual) codes, a 'second-order cybernetics', as it was later called by Heinz von Foerster, had meanwhile turned to other models: Stafford Beer developed his concepts in line with British cyberneticists such as Grey Walter, W. Ross Ashby, or Gordon Pask. As the historian of science Andrew Pickering (2009) pointed out, their common denominator was a turn to biological models. Beer, for the field of operational research concepts, sought for concepts that could ensure the survivability of firms, institutions (and later states) in uncertain, fluctuating, and changing environments. This evolved into his Viable System Model (VSM):

"Beer's idea was to read biological organisms as exemplary of the structure of viable systems in general, and to transplant the key features of their organization to the structure of the firm. In particular, he chose the human nervous system as his model. In the VSM, then, Beer's strategy was to transplant the 
Fig. 3 Reprinted from: ISO-

TYPE Bildstatistisches Elementarwerk (1930). With permission from Österreichisches Gesellschafts- und Wirtschaftsmuseum, Vienna

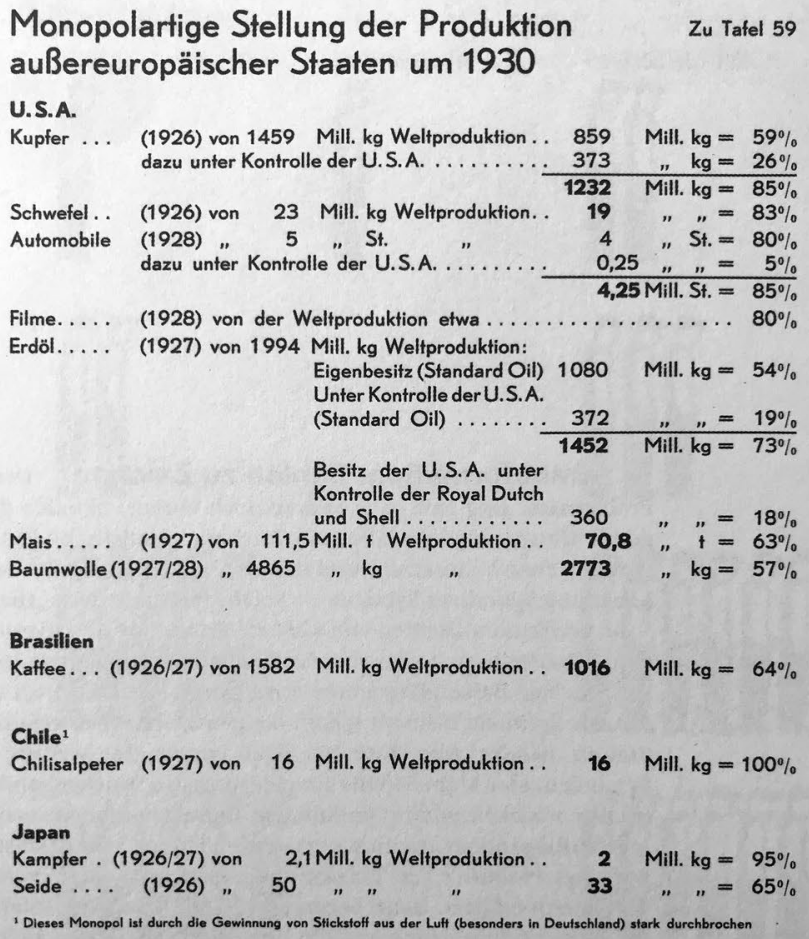

Monopolartige Produktionen aussereuropäischer Länder $\frac{\text { U.S.A. }}{\text { Kupleat }}$
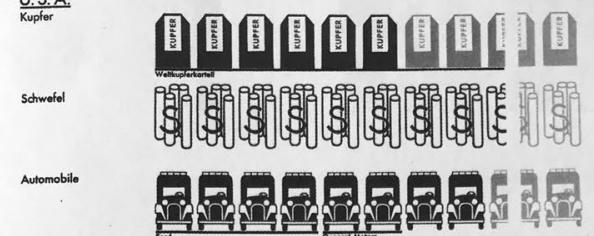

Kinotime

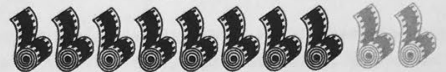

Erdöl

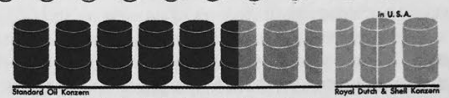

Mois

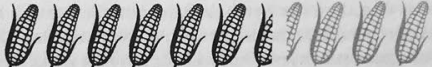

Boumwolle

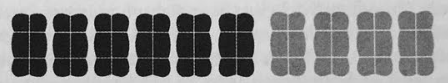

BRASILIEN

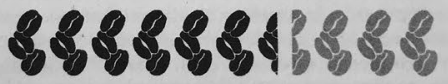

CHIIE

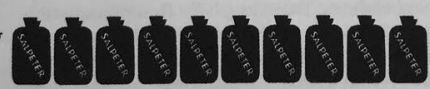

IAPAN

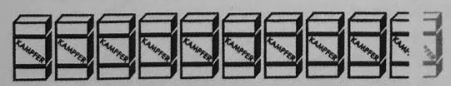

Seide

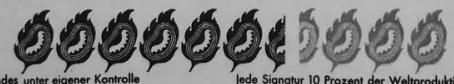

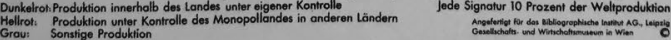


Fig. 4 Reprinted from: ISOTYPE Bildstatistisches Elementarwerk (1930). With permission from Österreichisches Gesellschafts- und Wirtschaftsmuseum, Vienna

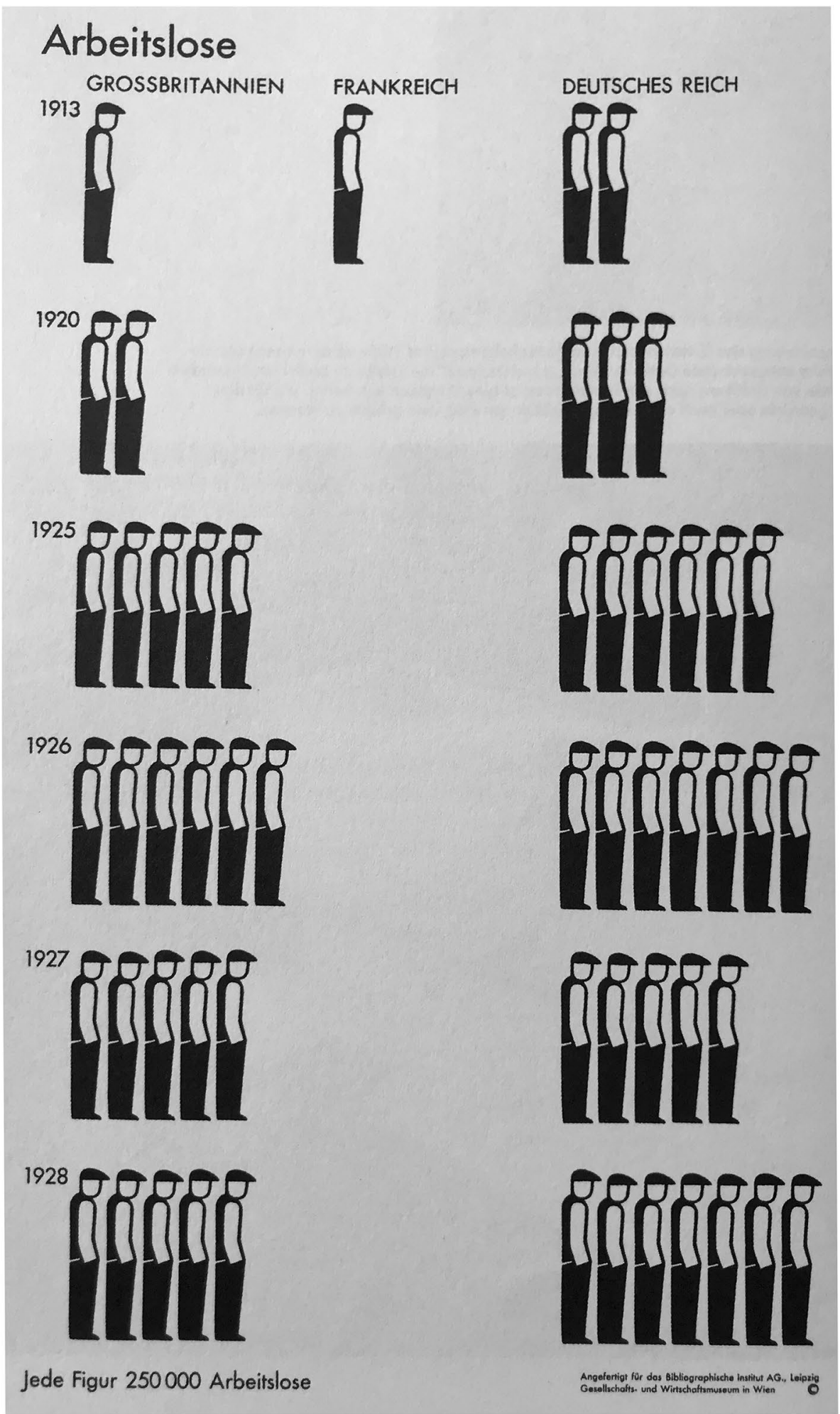

organic into the social [...]. [...I]nformation flows and processing would be laid out as a diagram of human bodily flows and transformations" (Pickering 2009, p. 244) (Fig. 7).
Beer provides his VSM with a universal, invariant organizational structure of five interconnected, homomorphic systems: System 1 is formed by the environment, the operative domain, and a steering unit. It contains all components to 
Fig. 5 Reprinted from: ISOTYPE Bildstatistisches Elementarwerk (1930). With permission from Österreichisches Gesellschafts- und Wirtschaftsmuseum, Vienna
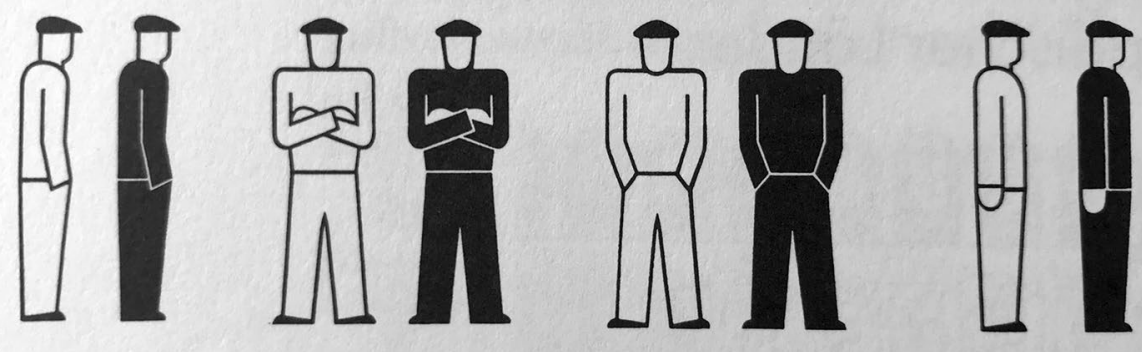

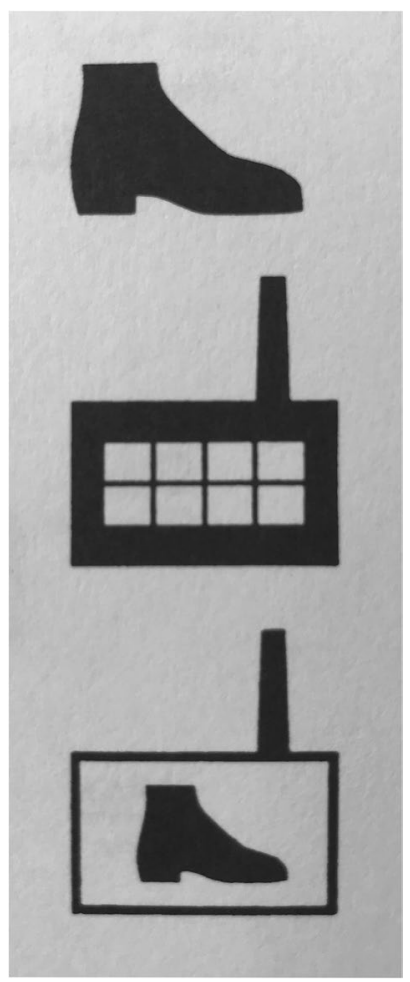

Fig. 6 Reprinted from: ISOTYPE Bildstatistisches Elementarwerk (1930). With permission from Österreichisches Gesellschafts- und Wirtschaftsmuseum, Vienna

be able to maintain its identity independently. An example would be the production workshop of a factory. System 2 coordinates demarcation problems between the different systems 1 . If, for example, two different production workshops want to use the same raw materials, this is coordinated by system 2 . System 3 comprises the overall operational management of the social system, in our example "functional areas such as purchasing, finance, production, human resources, marketing and sales" (Adam 2001, p. 84). It is the "managerial fulcrum of viable organizations [...]. System

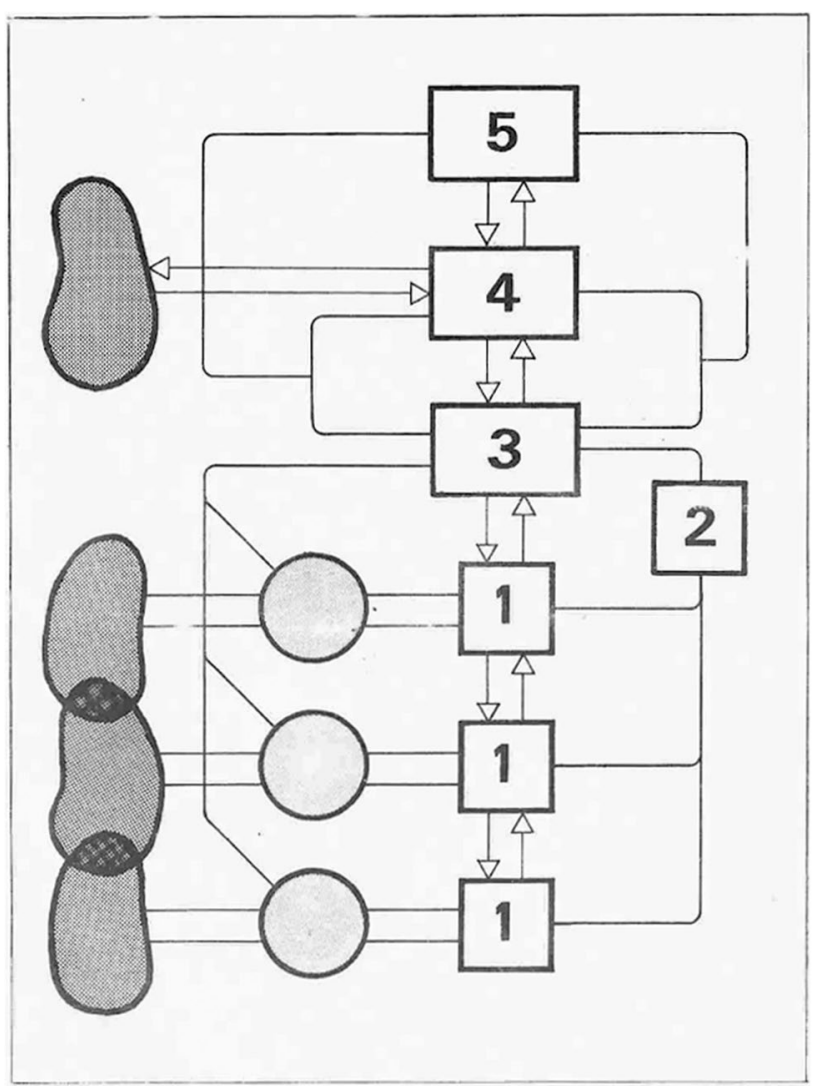

Fig. 7 Reprinted from: Barrientos J, Espejo R (1973) Un Modelo Cibernetico Para La Direccion Del Sector Industrial. INTEC 4, 5-18: 8. With permission from the National Development Corporation Corfo

Three in practice really runs the entreprise" (Beer 1979, p. 263). It implements the strategic success factors of an enterprise, observes systems 1 and 2 and links them with systems 4 and 5: "[System Three] is aware of all that is going on inside the firm, now" (Beer 1979, p. 202) and determines the relationship between the cohesion of the overall system and the autonomy of the individual systems 1 . System 4 of the 
social system has the task of maintaining contact with the environment of the entire unit from the subordinate systems and of observing the future development of the environment. Implemented in the form of the Opsroom, it is "concerned to manage the outside-and-then" (Beer 1979, p. 210): "On the one hand, it observes the already well known and less problematic environment and tries to identify and assess future trends. In addition, it observes the environment classified as problematic and tries to recognize new developments. [...] To perform these 'feed-forward' functions[...] system 4 needs evaluation criteria from system 5" (Adam 2001, p. 90). Finally, system 5 has normative management functions, is the "logically last steering unit" of the system, and "together with systems 3 and 4, determines the success factors and normalizes the behavior of the parts by means of general stabilization criteria, such as corporate policy and behavioral guidelines" (Adam 2001, p. 93). In principle, however, the subsystems should act autonomously and only send so-called algedonic signals to higher system levels in an emergency. The basis of the VSM thus was formed by three design principles: viability, recursivity, and autonomy:

"For Cybersyn the design was reducing the large complexity of production activities at all structural levels [...] and the disturbances buffeting them, to relevant information for management. The point was ignoring what deserved to be ignored and reporting significant changes. An aim for variety engineering in the project was offering a model driven approach to reducing situational complexity to a manageable level, while at the same time improving performance. The hypothesized recursive structure was used as a platform to design performance indices, based on the actualities (ACT), capabilities (CAP) and potentialities (POT) of essential variables for all the operational units, from the local to the global. The intention was measuring in real-time significant changes in the behavior of essential variables for workers and managers" (Espejo 2014, p. 82).

This was exactly where the design team came in. Quite fittingly, around 1970 Bonsiepe had begun to elaborate the concept of the interface for design theory. As German art historian Roland Meyer has pointed out, Bonsiepe's 1974 volume Design im Übergang zum Sozialismus sought to subsume his various INTEC projects under this term and "used it as a theoretical tool to redefine the scope of industrial design as a discipline." Bonsiepe's concept of the interface thus already exceeded the context of data processing systems and, on a more abstract level, turned into a heuristic to re-focus design processes on the "relationships" between people and objects (Meyer 2019, p. 238):

"Industrial design, in this perspective, acts in the inbetween, devising the intermediate, both material as well as semiotic layers necessary to provide human subjects access to the increasingly complex world of technical artefacts they live in. Thus, not only the Opsroom, but also the dosing mechanism of a sowing machine could now be understood as an interface: it had to be readable and understandable, it had to convey a sense of the possible uses of the machine and provide access to its operative resources, and in doing so, it structured a common sphere of communication and interaction between people and their artefacts." (Meyer 2019, p. 238)

However, Bonsiepe's occupation with the Opsroom user interfaces became the most illustrative example of his theoretical ponderings. With regard to the principles of Beer's VSM, its elements had to be designed in such a way that they were intuitively understandable and could be accessed even by (computer-) illiterate users. And they had to support the speed of decision-making:

"In short, everything we know in psychology about perception, pattern recognition, and (in general) awareness of the state of affairs, says that we should try to reach our judgements in terms of relative size and shape, relative color, relative movement. When we draw graphs and histograms, we pay attention to the first of these desiderata-but even then, having reached the judgement as a matter of fact, we have then to make it look 'respectable' by quoting rows of digits. But our control center would leave the handling of digits where this kind of work belongs: inside the computer. Managers would be trained to deal with other kinds of display, essentially graphic, but depending profoundly on relative movement-a mode of communication so very well understood in all biological spheres that it is well nigh incredible to find it not exploited in the sphere of human affairs" (Beer 1981, p. 193).

The uniform, standardized design of the graphical interface elements thus played an important role. And the visual grammar of the Opsroom developed for this purpose was already expressed in the Central Screen of the Opsroom. It set the scene for the VSM: "[M]ade of acrylic in bright amusing colors" (Bonsiepe 1972), it is one meter wide and two meters high, equipped with "[...] low voltage lamps. Easy to make. Regulable in intensity" (Bonsiepe 1972) (Fig. 8). For Beer, the central position was essential: it should always remind decision-makers of the cybernetic principles that their decisions were based on. But according to Medina, the deeper meaning of the model - and thus of the Central Screen-remained obscure to most of those involved (Medina 2011, p. 121). 


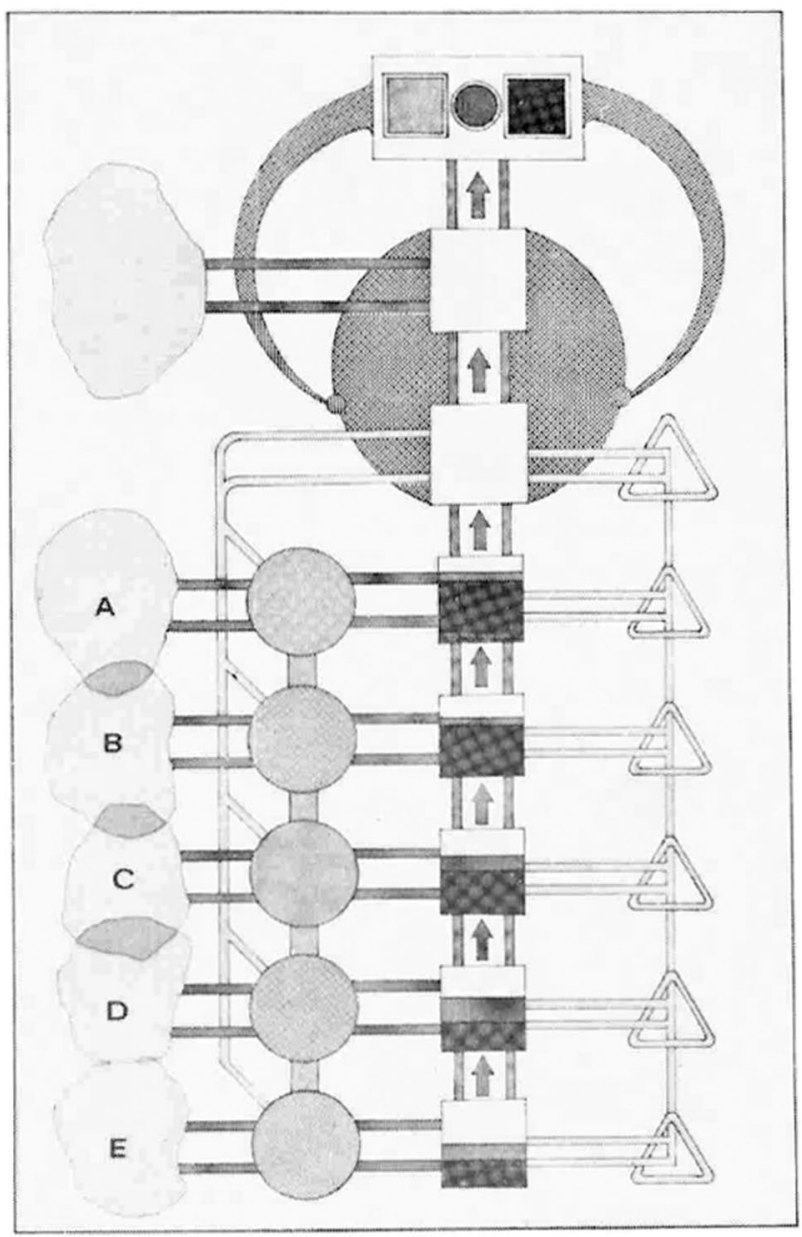

Fig. 8 Reprinted from: Grupo de Proyecto de Diseño Industrial INTEC/CORFO (1973) Diseño de una Sala de Operaciones. INTEC 4, 19-28: 23. With permission from the National Development Corporation Corfo

The first thing that caught the eye was a series of circles. These showed which operations the working group was currently dealing with. Because of the recursiveness of the VSM system, the diagram could ultimately represent any level of the overall system. In addition, there were rectangles. They represented the potency of the operations and contained the levels for capability and activity as red and green "liquids". The rectangles thus represented the latency as well as the productivity indices of the respective operations in one icon. This allowed an immediate overview of their relations to each other (Beer 1973, p. 21).

The relations and loops between the systems and operations shown on the VSM screen were represented by animated lines to emphasize their dynamics. The movement and flow effects were created by rows of rotating discs which illuminated colored plastic strips on the screen surface (see Schwember 1977, p. 127). This differed from conventional representations of dynamic systems: "There

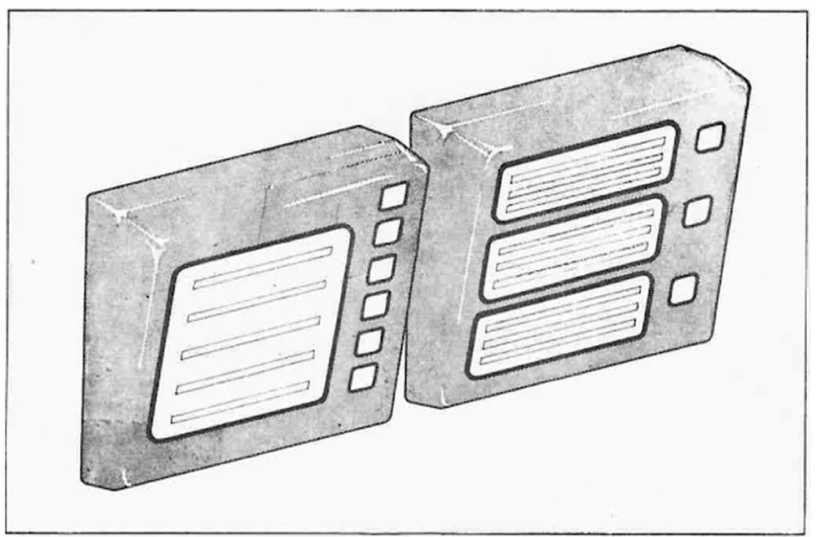

Fig. 9 Reprinted from: Grupo de Proyecto de Diseño Industrial INTEC/CORFO (1973) Diseño de una Sala de Operaciones. INTEC 4, 19-28: 24. With permission from the National Development Corporation Corfo

are no arrows to be seen $[\ldots]$, just moving lines. Scientists often suppose that to mark a line with an arrow makes it clear that the total system so encumbered with arrows is actually dynamic. Not so, people read the arrows as indicating directional, but still static relationships" (Beer 1973, p. 21). Furthermore, the tempo of the line movement could be varied by faster or slower rotation of the disks, "which tells the brain a great deal about the relative lags in the system", whilst horizontal red lines indicated disturbances (Beer 1973, p. 21). Details then were displayed on a so-called exception screen. And finally, there was also a display for algedonic signals of subordinate recursion levels. These were represented by red flashing arrows and each of these signals activates the so-called Algedonic Screen (Beer 1973, p. 21; 1981, p. 269) (Fig. 9).

The urgency of the algedonic signals was reflected in three color ranges: a green range in which the problems were listed whose solution was dealt with on the same recursion level; a yellow range for problems whose solution attempts were already passed on to a higher level; and a red range for problems which had to be dealt with on the highest level (Schwember 1977, p. 128).

To back up decisions, a second operating system was installed. This so-called Datafeed consisted of three analog data screens arranged side by side under a larger index screen (Fig. 10).

All four screens were made of fiberglass-reinforced plastic (Bonsiepe 2004) and used rear projection technology. On these screens, background information could be called up that was stored in the iconic form in a slide archive. Its depicted flow and bar slides had previously been drawn on cardboard, filled with color, and then photographed (Bonsiepe 2004) Behind each data screen were five automatic carousel slide projectors, each of 


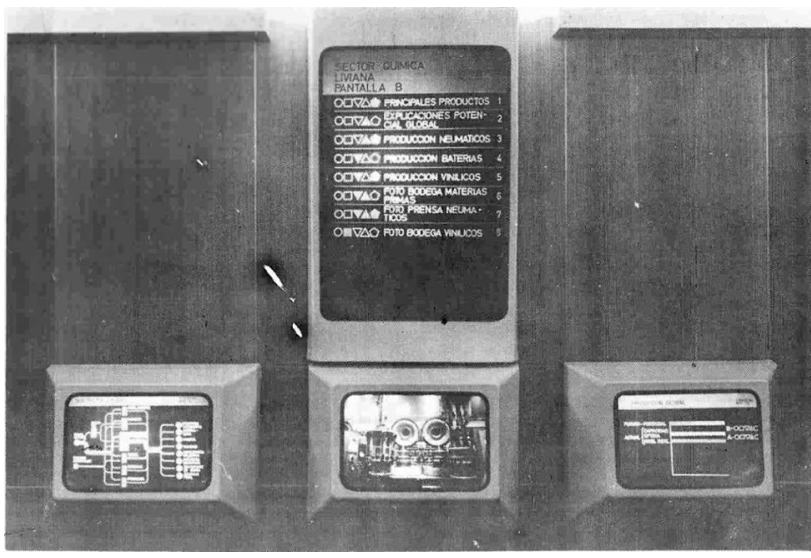

Fig. 10 Reprinted from: Grupo de Proyecto de Diseño Industrial INTEC/CORFO (1973) Diseño de una Sala de Operaciones. INTEC 4, 19-28: 22. With permission from the National Development Corporation Corfo

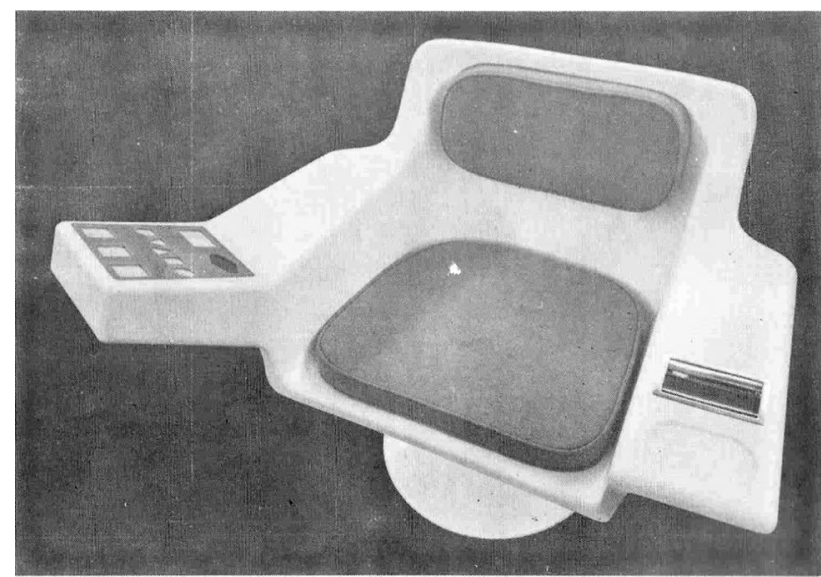

Fig. 11 Reprinted from: Grupo de Proyecto de Diseño Industrial INTEC/CORFO (1973) Diseño de una Sala de Operaciones. INTEC 4, 19-28: 21. With permission from the National Development Corporation Corfo

which holding eighty slides with iconic or brief written information.

The screens were operated by a panel of 'big-hand controls' embedded in the armrests of the five to seven Opsroom seats (Beer 1981, p. 270) (Fig. 11).

A large diamond-shaped button in the bottom row was the so-called control button which addressed Datafeed (Beer 1973, p. 22). The user was able to access the index screen by means of the large rectangular button in the bottom row or select one of the data screens by pressing one of the three square buttons in the top row of the armrest. With respective combinations of five buttons in the middle row, he could then call up and navigate subdirectories. It gave Datafeed a kind of hypertext structure with slides linked by key combinations_-an audacious mixture of anachronistic and forward-looking media technology which, according to Beer, also served a creative and dynamic interaction (Beer 1973, p. 22). In any case, tests with subjects untrained in the use of the data feed system prove its intuitive operability: "Moreover, any participant would learn in a few minutes, as the actual tests effectively showed, how to use the control screen and the corresponding panel at his chair" (Schwember 1977, p. 128).

The visual design of the slides followed a fixed set of rules to guarantee a standardized way of presentation. Although few documents have survived the Chilenean coup d'état of 1973, Bonsiepe later recalled some guidelines of the Opsroom's visual grammar: For instance, at Beer's request, there were only three different types of flow lines. A thin line 5-6 $\mathrm{mm}$ wide (thus providing just enough space for a line of text), symbolizing a quantity fraction of $0.1-10 \%$ of a corresponding substance. A medium-thick line $(10-12 \mathrm{~mm})$, representing a proportion of $10.1-50 \%$. And a thick line (20-24 mm) representing a proportion of $50.1-100 \%$. There were also uniform rules for dividing and for angled flow lines (see Bonsiepe 1972).

Production units were symbolized as vertically arranged rectangles. By dividing these rectangles horizontally, a changing "waterlevel" indicated the relation of the current level to the optimal capacity. Bonsiepe proposed as colors an intense blue for the current capacity and red for the latency area. The larger the red area would become, the more strongly this would symbolize an imminent source of danger. For the basic color scheme of quantified flowcharts, Bonsiepe preferred a dark, i.e., gray or dark blue background, and for the symbols depicted on them equally intense yellow, green, red, sky blue and light violet. In order to ensure that any additional written information was sufficiently legible, the team used the typography of an IBM typewriter (see Bonsiepe 1972) (Figs. 12 and 13).

As a third element, the so-called Futures system was implemented by means of two screens. One of them is again a simple back-projection screen reserved for showing simulations. The aim was to generate and evaluate scenarios for the development of the most important economic parameters for the next 10 years. It was based on the same DYNAMO compiler of computing engineer W. Jay Forrester's research group at MIT which gained popularity in the context of the Club of Rome's Limits to Growth studies at the same time (Forrester 1965, 1969, 1972, 1973; Meadows et al. 1972). But the data compiled and processed by the Cybernet information network behind Datafeed remained too fragmentary and scattered for the intended purpose. The second screen for the Futures system was a large metal panel (see Bonsiepe 2003) (Fig. 14) was meant to show the flow diagrams of a DYNAMO simulation. For this purpose, it had to be possible to change the structure of the flow diagram to allow experimentation 
Fig. 12 Reprinted from: Grupo de Proyecto de Diseño Industrial INTEC/CORFO (1973) Diseño de una Sala de Operaciones. INTEC 4, 19-28: 27. With permission from the National Development Corporation Corfo
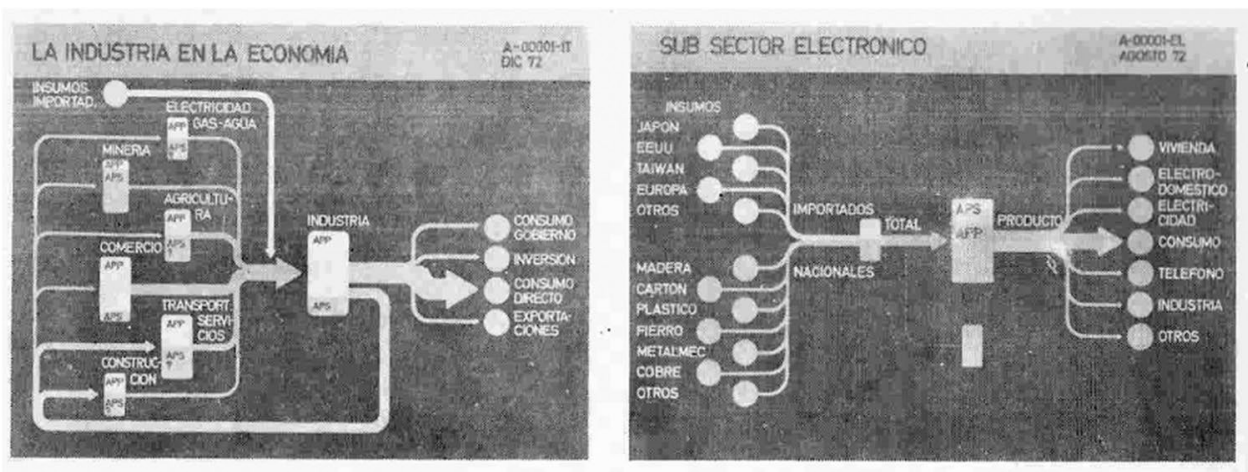

Figura 1

Figurā 2
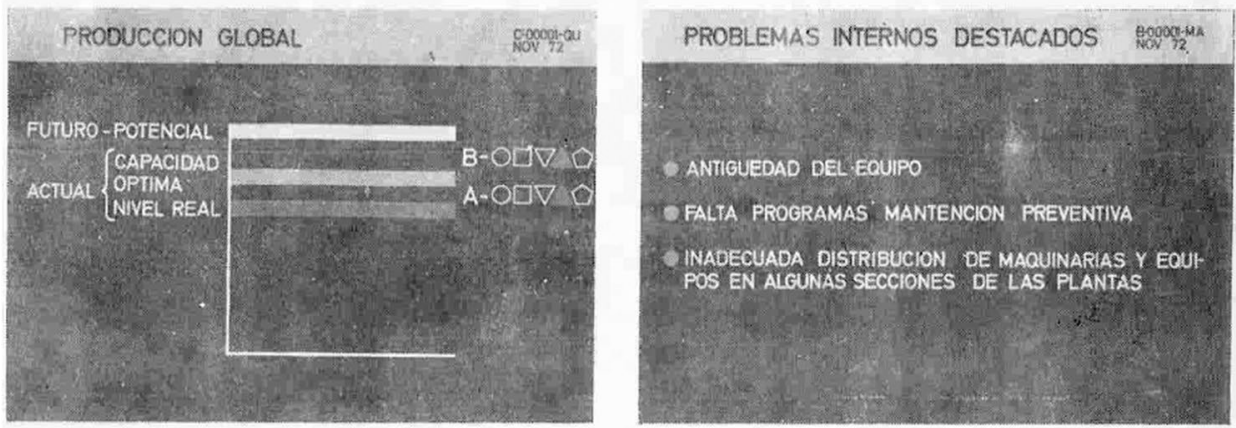

Figura 3

Figura 4

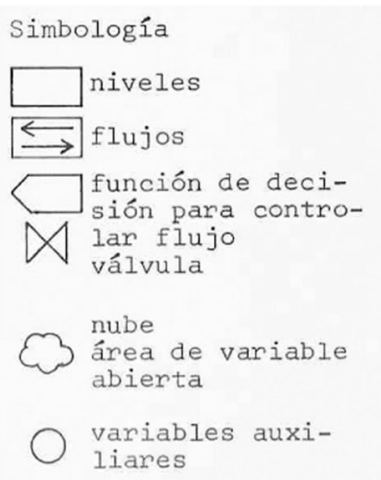

Fig. 13 Reprinted from: Grupo de Proyecto de Diseño Industrial INTEC/CORFO (1973) Diseño de una Sala de Operaciones. INTEC 4, 19-28: 25. With permission from the National Development Corporation Corfo

with different control data and influence variables to mirror adjustments to the computer model. (Beer 1973, p. 22). This was realized with the help of a metallic surface to which flexibly formable magnets could be attached. The magnets, in turn, carried plastic strips in different colors, analogous to the animated lines in the VSM model of the

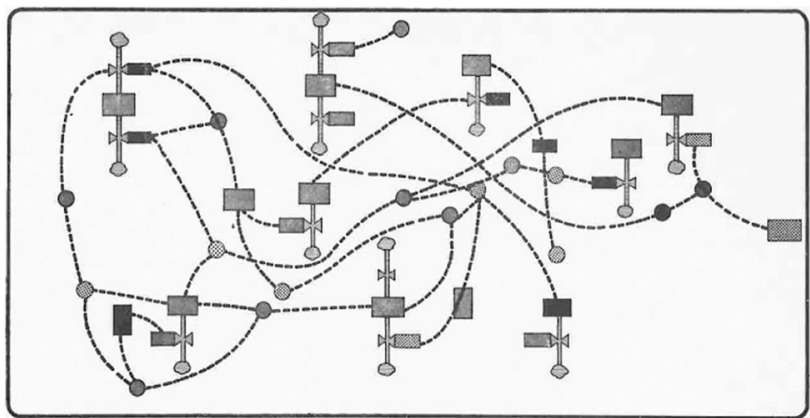

Fig. 14 Reprinted from: Grupo de Proyecto de Diseño Industrial INTEC/CORFO (1973) Diseño de una Sala de Operaciones. INTEC 4, 19-28: 25. With permission from the National Development Corporation Corfo

Central Screen, which could be "bent into the desired figurations" (Bonsiepe 2003). The other symbols needed for the flowchart were also magnetically positioned. And also, this screen was animated, with the light projected from a device under the ceiling (Schwember 1977, p. 128).

A fifth wall of the Opsroom remained empty. It was reserved for the installation of an Algedonic Meter for a planned system called Cyberfolk: 
"The idea was that the (electrical) People's Assembly, disseminated throughout the nation, would be able to participate in arguments broadcast from the room-not by responding to questions hurled at them over the air, for this route leads to logical reductionism and to political demagoguey; but-by the continuous registration of a combined degree of satisfaction with events. It has to be noted that not only would the meter be visible to those present in the room, but also to the public whose meter it is..." (Beer 1981, p. 284).

Alas, the wall remained empty because Cyberfolk did not get beyond the concept stage (Medina 2011, pp. 88-92).

In sum, it can be stated that the interface design of the Operations Room was oriented towards an operativity of communication: It implemented information design — based on information-aesthetic considerations and visual grammars-in an interactive and attention-economically refined interface design. The design team aimed to connect human users to complex, dynamic decision environments as effectively as possible. In the Opsroom, elements of first-order cybernetics were thereby synthesized into an 'observer position' that, quite in the spirit of thinking in terms of secondorder cybernetics, references both the system levels of the VSM and itself.

But to what extent this approach was really thought through to the end remains questionable. As is well known, Beer attached great importance to an informal atmosphere between all the interfaces: "'Saloon' atmosphere by indirect light, regulable in brightness. Bar for Pisco sours and so on," Gui Bonsiepe noted in a letter to Beer. Ashtrays were installed in the armrests of the seats- "Beer was an intense Cuba cigar smoker" (Bonsiepe 2004), and the Opsroom was to be used as a 'clubhouse' (Beer 1979, p. 243), thus "demystifying" the work in the management and economic planning area (Bonsiepe 2004) and incorporating another creative communication resource: For " $[\mathrm{t}] \mathrm{he}$ third mode of interaction, the informal, is by far the most effective" (Beer 1981, p. 193). However, in retrospect, Raùl Espejo, for example, criticized precisely the strong focus on interface design:

"As for the Operations Room, from a methodological perspective Cybersyn stressed constructing a conversational technology rather than designing conversations. It offered a technology to include people in policy processes but did not offer a methodology for their meaningful inclusion. [...] It was an instance of a technology-dominated agenda at the expense of enhancing the autonomy of enterprises and therefore contributing to the performance of the national economy. Beer's later work in Team Syntegrity was a powerful methodological contribution to designing conversations. Indeed, varied technologies are now available to enable these conversations that were unthinkable in those days, and they give credibility to Beer's vision 40 year ago"

(Espejo 2014, p. 89)

And Karen Benezra even went so far as to describe Cybersyn as a "Revolution in Style" whose preoccupation with (dysfunctional) technology and whose elitist conceptual articulation rather thwarted its good intends: "Beer's description of the Operations Room reinforces the residual, if not integral, hierarchy, as well as the division between manual and intellectual labor evident in the Viable System Model" (Benezra 2018, p. 205). But as Espejo and Medina suggest, the Opsroom can also be seen as a starting point for questions of interaction design that do not merge into the design of technical interfaces. This also transforms the perspective on the involvement of design: In the first step, information design was concerned with a scientification of design processes and with new approaches to the operationalization and quantification of communications. This was expressed, among other things, in semiotic considerations and in the formulation of visual grammars. Then, in a second step, the interface design of the Opsroom intended to make an abstract cybernetic control loop model and its complex interactions and feedback effects cognitively and attentively comprehensible through the exemplary application of such grammars. In a third step, the approaches to interaction design cited below, proposed on the one hand by Beer, and on the other by Fernando Flores in their later career phases, are much more oriented to everyday and interpersonal practices in the context of management and organizational theory. The turn from 'conversational technology' to the 'design of conversations' urged by Espejo was expressed in Beer's work in a method called Team Syntegrity which, based on a geometric model, was designed to increase the effectiveness of communication. Flores, meanwhile, in collaboration with computer developer Terry Winograd, turned to the design of HCI. They built on much smaller-scale technical support media and operated by means of linguistic elements. In these examples, one might say, the central role of visual grammars was replaced by a (computer-based) management grammatology.

\section{Interaction design: team syntegrity and coordinator}

Albeit Espejo's criticism hits a point, Stafford Beer already in 1970 began to envision a communicative setup to facilitate and optimize decision making and problem solution processes in groups. However, almost 25 years passed after he introduced some elements in the organization of the Operational Research Society's annual meeting-he was its acting president at the time--before Beer published the final 
version of his Team Syntegrity method (Beer 1970; 1994). "Inspired by Stafford's realisation that all the good ideas at a conference come from the corridors and the bars" (Bechler 2002 , p. 3), it centers around a geometrical structure called the icosahedron, the most complex of the Platonic bodies, composed of 20 equilateral triangles, and with 30 edges and 12 vertices.

In resonance with R. Buckminster Fuller who used efficient and robust structures of equilateral triangles as basic elements for his geodesic domes, Beer's idea was to use the same structure for creating efficiency and robustness in communication (Fig. 15): The 12 vertices represented 12 problems to be solved or topics to be discussed, and each edge represented a member of a group of 30 people from diverse backgrounds. Thus, by generating a high amount of variety, the non-hierarchical geometrical model nevertheless created a multi-layered cohesion: Five persons were connected to each topic, whilst every person was a member of two topics. In addition, each person functioned as a critic for yet two further topics, and as an observer of yet another four. Played in three rounds, it was designed to minimize information paths and to maximize possible exchange on all topics for each group member whilst at all times rendering clear the division of tasks. This, according to Beer, resulted in a coordinated and comprehensible plan of action. Conflicting goals thereby were levelled by the integration of distributed knowledge into a shared way of conceiving a multi-dimensional problem space (Pfiffner 2004, pp. 7-8). Participants indeed reported that the "agreements we secured were beyond the normal kind of 'consensus', as Stafford promised us they would be. They were based on a much more thorough-going understanding

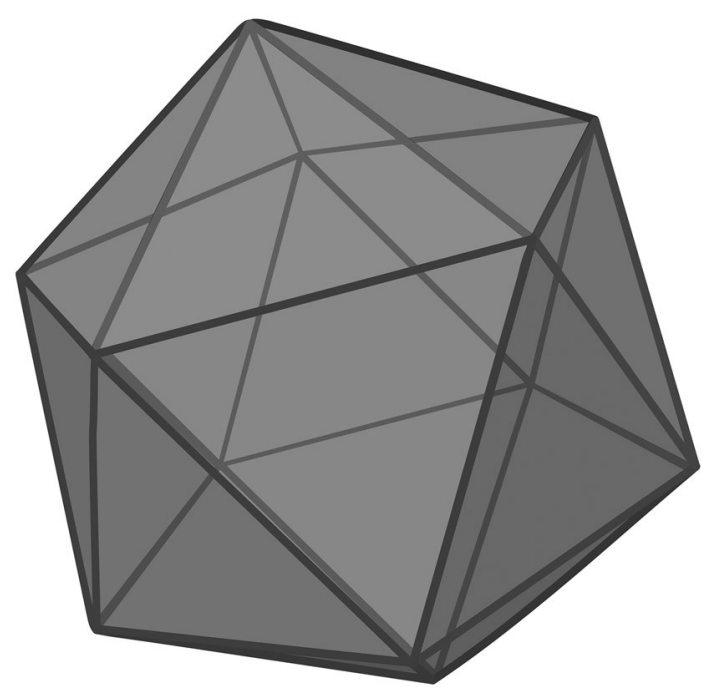

Fig. 15 Reprinted from: Wikipedia Article on Icosahedron, https://en. wikipedia.org/wiki/Icosahedron\#/media/File:Icosahedron.svg Permission granted under Common Licence CC BY-SA 3.0 of each other's point of view, and some core insights which soon emerged from very different types of small-group conversation to 'reverberate' throughout the whole event" (Bechler 2002, p. 3). And most prominently, the method became part of the peace talks between Israel and Palestine in 1995.

In addition, Fernando Flores, one of the main scientific initiators and political supporters of Project Cybersyn, expanded on its original cybernetic concepts during his later career. After an Amnesty International initiative lead to his release from imprisonment three years after Pinochet's coup and brought him to Stanford University, he made the acquaintance of computer scientist Terry Winograd. In close collaboration, Flores and Winograd during the late 1970s and 1980s developed concepts for Human-Computer Interaction and communication in organizations: "In order to understand the phenomena surrounding a new technology, we must open the question of design-the interaction between understanding and creation" (Winograd and Flores 1987 , p. 4). Flores thereby turned away from his Chilean experience of management cybernetics and towards an exploration of the more embedded and intuitive character of most communicative acts. As Medina notes, he "found that management through variety control did not allow intuitive forms of decision making, nor did it account for the previous experiences and cultural situation of decision makers" (Medina 2011, p. 231).

Likewise, building upon his expertise in AI research, Winograd challenged the early cybernetic thinking of creating computing machines and later so-called expert systems and decision support systems that would objectively represent the dynamics of complex systems. Both Flores and Winograd acknowledged the importance of the context of decision making and criticized most management scientist's tendency to focus on inherent decision structures. And together, they explored the possible impacts and potentials of novel computing technology to assist in the design of interactions under the assumptions of incomplete information and unstructurable problem spaces (Flores and Winograd 1987, p. 145). Their objective was to codify and make effective the directives and agreements at the core of business conversation, resulting in Flores' dissertation about an Office of the Future (1982) and in their seminal, co-authored book Understanding Computers and Cognition (1987). Both publications thereby unmoored heaps of phenomenological philosophy, speech act theory, and philosophy of mind to underline the crucial role of language for coordinated action (Winograd and Flores 1987, p. 176). Following philosophers Austin (1962) and Searle $(1969,2008)$, they claimed that communication exceeds the exchange of 'information' by substantially relying on prompts for action. With properly organized linguistic acts, novel opportunities could be identified and information 
overload be prevented (Flores et al. 1988, pp. 158-159). And computer technology contained potentials to assist in these coordination processes:

"The computer is ultimately a structured dynamic communication medium that is qualitatively different from earlier media such as print and telephones. Communication is not a process of transmitting information or symbols, but one of commitment and interpretation. A human society operates through the expression of requests and promises among its members. There is a systematic domain relevant to the structure of this network of commitments, a domain of 'conversation for action' that can be represented and manipulated in the computer" (Winograd and Flores 1987, p. 176).

Computers were to be understood as 'machines for acting in language', whose scope of action, however, was always limited by their programming and their conceptual presuppositions. Winograd and Flores criticized, in particular, the rationalistic tradition, which, with concomitants such as biases about objectivity, about the nature of 'facts' (or 'data', or 'information') and their origin, and about the role of the individual interacting with the computer, has been the dominant view in the development of Management Information Systems or Decision Support Systems up to now.

They suggested an alternative direction of development that replaces the formal settings and communicative expressions of existing computer applications with more 'life-like' program environments. "Successful interaction design," Winograd will write retrospectively, "requires a shift from seeing the machinery to seeing the lives of the people using it" (Winograd 1997). Computer applications should be designed regarding a conversation structure that was not determined by the structure of the machine, but is characterized by the ability to actively animate and reorient human communicative processes-or, in short: by their 'behavior' (Winograd 1979).

For example, Flores developed coaching procedures in which the embedding of the participant's speech acts in a network of human commitments is explored and new sets of linguistic domains were derived, which were then transformed into computational structures. Thereby, new distinctions and descriptions were created that would alternate the course and content of 'conversations for action' (Winograd and Flores 1987, p. 179). Or, in the words of Flores: "Computer technology involves machines, but that is not what is ultimately significant. It encompasses the design of new practices (including those of word processing, electronic communication, printing, accounting, and the like)" (Flores et al. 1988, p. 153). And these would have to be connected within a unified and coherent approach towards HCI design: "The vast number of specialized and idiosyncratic tools and practices can be incorporated into a coherent theory that leads to an effective redesign of already existing tools and to fruitful new possibilities (Flores et al. 1988, p. 159).

Winograd and Flores translated their work on language/ action theory into concrete software in their start-up Action Technologies, founded in the mid-1980s. There, together with the later JAVA developer James Gosling as a programmer, they developed the groupwork suite Coordinator that organized office life around linguistic distinctions:

"Instead of providing a uniform command to initiate a new message, The Coordinator provides options that identify different linguistic actions. When 'Request' is selected, the user is prompted to specify an addressee, recipients of copies, a domain (a keyword that groups related conversations under a common concern), and a brief action heading (corresponding to the subject header in traditional mail systems). The body of the message is prompted with the phrase 'What is your request?' to which the user enters any text whatsoever. The system makes no attempt to interpret this text but relies on the user's understanding and cooperation that the message is properly identified as a request. This is a key design issue: Let people interpret the natural language, and let the program deal with explicit declarations of structure (such as the user's declaration that this is a request)" (Flores et al. 1988, p. 160).

Constitutive for the effectiveness of the software was that it gave users the opportunity to observe the temporal constitution of actions through defined communication acts on the basis of a very sparse, menu-based graphic. But the Соттиnicator was not very successful with this direct, binding type of order and feedback. The US journalist Jerry Pournelle, in a Byte Magazine article, even called the direct command language "fascist software" (Borchers 2018). Elsewhere, the software met with fierce opposition from unions which rejected the time-accounting system behind it. Such criticism of its 'missionary' aspect was entirely expected by its developers:

"The implication is that organizational or social change is being imposed on an unwilling populace by outsiders with a dogmatic theology. Although this kind of manipulation is possible in principle, the technology is likely to be rejected, ignored, or subverted in practice. But from a different perspective, The Coordinator is a new kind of 'educational software' in which the everyday use of its communication tools serves to educate users in the principles of conversation and action." (Winograd and Flores 1987, p. 170)

As small as the commercial success of the Coordinator has been, as lasting was the influence of the abovementioned combination of explicit theoretical groundings and coherent $\mathrm{HCI}$ design principles for future developments in that 
emergent field. Flores' and Winograd's collaborative work took the point seriously that design should be occupied with the construction of the 'interspace' in which people live, "inhabited by multiple people, workstations, servers, and other devices in a complex web of interactions", rather than with an 'interface' with which they interact (Winograd 1997, p. 153). Interaction Design thus has to be distinguished from later advancements, e.g. regarding the graphical surfaces of HCI. That is, Winograd notes, because HCI is a field "with interdisciplinary concerns, since its essence is interaction that includes people and machines, virtual worlds and computer networks, and a diverse array of objects and behaviors." This more encompassing notion of interaction design thus precedes attempts at creating novel graphical user interfaces, and thus, in a way, re-oriented the mere technology- and interface-centered design approach of the Cybersyn Opsroom.

\section{Conclusion}

This article attempted to discuss Project Cybersyn as a medium in a multiple sense. First, with a focus on design history, it can be perceived as a node which connects historical vanishing lines into picture languages and typographic systems with a universal and international approach. Second, it links and articulates different characteristics of design with respect to computation technology which span from information design via interface design to interaction design. It excavates as their common denominators a transdisciplinary mindset and a connection to cybernetic principles, but also identifies shifts from a preoccupation with semiotics to linguistics, from abstraction to concretion, and from 'information' to the 'informal' elements of 'communication for action'. Third, Cybersyn can be seen as a medium which connects first and second-order cybernetics. Its Opsroom signifies a capacity for self-reflection in the self-referential structure of Beer's VSM, facilitated by interface designs which pay tribute to early information-theoretical groundings. Fourth, the project linked people from such dispersed places as Chile, Argentina, Germany, the United Kingdom, Austria, and the US and thus generated a particular international network of pre-, post-, and actual cybernetic thought. And not least, the article tried to embed Project Cybersyn in a multi-dimensional network of attempts towards 'operative communication' whose conceptual elements still resonate today in such diverse fields as Computer-Supported Cooperative Work, information visualization, or the design of computer control centers and smart city dashboards. Beyond Cybersyn's real and imaginative connections to contemporary discourses on datafied decision making or the governmentalities of big data, it is this position in the history of design that attaches it to an archaeology of the present.
Acknowledgements The author wants to express his gratitude to MECS research student Stefanie Pieper for her assistance with the copy-editing of this article.

Funding Open Access funding enabled and organized by Projekt DEAL.

Open Access This article is licensed under a Creative Commons Attribution 4.0 International License, which permits use, sharing, adaptation, distribution and reproduction in any medium or format, as long as you give appropriate credit to the original author(s) and the source, provide a link to the Creative Commons licence, and indicate if changes were made. The images or other third party material in this article are included in the article's Creative Commons licence, unless indicated otherwise in a credit line to the material. If material is not included in the article's Creative Commons licence and your intended use is not permitted by statutory regulation or exceeds the permitted use, you will need to obtain permission directly from the copyright holder. To view a copy of this licence, visit http://creativecommons.org/licenses/by/4.0/.

\section{References}

Adam M (2001) Lebensfähigkeit sozialer Systeme-Stafford Beer's viable system model im Vergleich. Dissertation, St. Gallen

Athanasiou T (1980) The liberty machine. Undercurrents Mag Rad Altern Commun Technol 38

Axelrod J, Borenstein G (2009) Free as in beer: cybernetic science fictions-a paper delivered at the 2009 Pacific ancient and modern languages association conference http://www.youtube. com/watch? $\mathrm{v}=\mathrm{hCO}$ vXyR-c4\&list $=$ PLF56B008626140E0A\& index $=1$. Accessed 9 May 2021

Barrionuevo A (2008) Before 73 coup, Chile tried to find the right software for socialism. New York Times (March 28)

Bechler R (2002) Stafford Beer-the man who could have run the world. Open Democracy https://www.opendemocracy.net/en/611/. Accessed 9 May 2021

Beckett A (2003) Santiago dreaming. Guardian (8 September)

Beer S (1973) Fanfare for effective freedom-cybernetic praxis in government. Carel Isaf Institute 2002. http://www.kybernetik.ch/dwn/ Fanfare_for_Freedom.pdf Accessed 9 May 2021

Beer S (1979) Heart of the enterprise. John Wiley \& Sons, Chichester

Beer S (1981) Brain of the firm, 2nd edn. John Wiley \& Sons, Chichester

Benezra K (2018) Cybersyn: a revolution in style. In: Fernández M (ed) Latin American modernisms and technology. ICM Book Series (Institute for Comparative Modernities (ICM) Cornell University)/ Africa World Press, pp 195-220

Bense M (1951) Kybernetik oder Die Metatechnik einer Maschine. In: Bense M, Walther E (eds) Ausgewählte Schriften, vol 2. JB Metzler, Stuttgart, pp 429-446

Bense M (1956) Aesthetica (Vol. II)—Ästhetische Information. Agis, Baden-Baden

Bense M (1965) Aesthetica-Einführung in die neue Aesthetik. Agis, Baden-Baden

Bonsiepe G (1968) Eine Methode, Ordnung in der typographischen Gestaltung zu quantifizieren/A method of quantifying order in typographic design. Ulm Zeitschr Hochschule Gestaltung 21: 24-31

Bonsiepe G (1972) Sketchs for the op-room. Brief an Stafford Beer. Computer scan, personal communication with the author, September 25, 2003 
Bonsiepe G (1974) Design im Übergang zum Sozialismus-Ein technisch-politischer Erfahrungsbericht aus dem Chile der Unidad Popular (1971-73). Hamburg, Red. Designtheorie

Bonsiepe G (1995) The invisible facets of the Hfg Ulm. Des Issues $11(2): 11-20$

Bonsiepe G (2003) E-mail to the author

Bonsiepe G (2004) E-mail to the author

Bonsiepe G, Maldonado T (1963) Zeichensystem für elektronische datenverarbeitende Anlagen (1960/61). Ulm Zeitschr Hochschule Gestaltung 8/9: 20-24

Borchers D (2018) Das Cybersyn-Projekt-Wie Chile einst die Zukunft der Planwirtschaft entwarf. c't Retro. https://www.heise.de/ select/ct/2018/27/1541215368236612. Accessed 9 May 2021

Espejo R (2014) Cybernetics of governance: the Cybersyn project. In: Metcalf GS (ed) Social systems and design. Translational systems sciences, 1 st edn. Springer, Tokyo, pp 79-98

Fernández S (2003) Der Einfluss der HfG Ulm auf die Designausbildung in Lateinamerika. In: Rinker D, Quijano M, Reinhardt B (eds) Ulmer Modelle, Modelle nach Ulm - Hochschule für Gestaltung Ulm 1953-1968. Hatje Cantz Verlag, Ostfildern-Ruit, pp 118-123

Flores F (1982) Management and communication in the office of the future. Dissertation, University of Berkeley

Flores F, Graves M, Hartfield B, Winograd T (1988) Computer systems and the design of organizational interaction. ACM Trans Office Inf Syst 6(2):153-172

Forrester JW (1965) Industrial dynamics, 4th edn. MIT Press, Cambridge

Forrester JW (1969) Urban dynamics. MIT Press, Cambridge

Forrester JW (1972) Grundzüge einer Systemtheorie (Principles of systems). Gabler, Wiesbaden

Forrester JW (1973) World dynamics, 2nd edn. Wright-Allen Press, Cambridge

Frank H (1963) Letter to Otl Aicher. Private Archive Helmar Frank, HfG Ulm Archive

Hartmann F (1997) Sprechende Zeichen-Otto Neuraths revolutionäre Methode der Bildpädagogik. Telepolis-Magazin der Netzkultur. https://www.heise.de/tp/features/Sprechende-Zeichen-3412788.html Accessed 9 May 2021

Herrmann H (2018) Geist der Abstraktion. Mathematik und Ästhetik bei Max Bense. In: Uhl E, Zittel C (eds) Max Bense. Weltprogrammierung. J.B. Metzler, Stuttgart, pp 83-94

Hartmann F (2000) Sprechende Zeichen - Otto Neuraths Internationale Bildsprache. In: Hartmann F (ed) Medienphilosophie. WUV, Wien, pp 147-166

Hartmann F (2002) Bildersprache. In: Hartmann F, Bauer EK (eds) Bildersprache-Otto Neurath. Visualisierungen, WUV, Wien, pp $15-107$

Khanna P (2017) Technocracy in America: rise of the info-state. Create Space Independent Publishing Platform

Kinross R (1991) Einleitung. In: Haller R, Kinross R (eds) Otto Neurath-Gesammelte Bildpädagogische Schriften, vol 1. HölderPichler-Tempsky, Wien, pp 9-23

Loeber K (2018) Big data, algorithmic regulation, and the history of the Cybersyn Project in Chile, 1971-1973. Soc Sci 7(4):65. https://doi. org/10.3390/socsci7040065

Maldonado T (1958) Neue Entwicklungen in der Industrie und die Ausbildung des Produktgestalters. Ulm Vierteljahresberich Hochschule Gestaltung 2:31-39

Mäntele M (2003) Magier der Theorie. In: Rinker D, Quijano M, Reinhardt B (eds) Ulmer Modelle, Modelle nach Ulm-Hochschule für Gestaltung Ulm 1953-1968. Hatje Cantz Verlag, Ostfildern-Ruit, pp 82-87

Mason P (2016) Post capitalism. A guide to our future. Penguin, New York

Meadows DH, BehrensMeadows Randers WWDLJ (eds) (1972) The limits to growth: a report for the Club of Rome's project on the predicament of mankind. Universe Books, New York
Medina E (2011) Cybernetic revolutionaries - technology and politics in Allende's Chile. MIT Press, Cambridge

Medina E (2015) The cybernetic revolution. Jacobin Magazine https:// www.jacobinmag.com/2015/04/allende-chile-beer-medina-cyber syn/. Accessed 9 May 2021

Mersch D (2018) Benses existenzieller Rationalismus. Philosophie, Semiotik und exakte Ästhetik. In: Uhl E, Zittel C (eds) Max BenseWeltprogrammierung. Metzler, Stuttgart, pp 61-82

Meyer R (2019) From artefacts to interfaces: Gui Bonsiepe and the re-definition of industrial design, c. 1970. Interface Critique J 2:235-241

Moles A (1968) Information theory and esthetic perception. University of Illinois Press, Urbana-Champaign

Mori E (2020) Olivetti ELEA sign system: interfaces before the advent of HCI. IEEE Ann Hist Comput 42(4):24-38. https://doi.org/10.1109/ MAHC.2020.3027581

Morozov E (2014) The planning machine. Project Cybersyn and the origins of the big data nation. New Yorker (6 October 2014)

Neurath O (1991a) Bildstatistik nach Wiener Methode. In: Haller R, Kinross R (eds) Otto Neurath-Gesammelte Bildpädagogische Schriften, Bd 3. Verlag Hölder-Pichler-Tempsky, Wien, pp 180-191

Neurath O (1991b) Museum of the future. In: Haller R, Kinross R (eds) Otto Neurath—Gesammelte Bildpädagogische Schriften, Bd 3. Verlag Hölder-Pichler-Tempsky, Wien, pp 244-257

Neurath P, Nemeth E (eds) (1994) Otto Neurath oder die Einheit von Wirtschaft und Gesellschaft. Böhlau, Wien

Noveck B (2015) Smart citizens, smarter state: the technologies of expertise and the future of governing. Harvard University Press, Cambridge

Pfiffner M (2004) From workshop to syntegration: the genetic code of effective communication. Malik Manage 10(4): 1-10. https://www. syntegration.com/_file/09_From+workshop+to+syntegration.pdf. Accessed 9 May 2021

Pias C (2002) Unschuldige Augen. In: Frank H, Bauer EK (eds) Bildersprache. Otto Neurath. Visualisierungen. WUV, Wien, pp 136-139

Pias C (2004) Zeit der Kybernetik-Eine Einstimmung. In: Pias C (ed) Cybernetics. The Macy-conferences 1946-1953, vol 2. Diaphanes, Berlin, pp 9-41

Pickering A (2009) The Cybernetic Brain. Sketches of another Future. Chicago UP, Chicago

Rinker D (2003) Produktgestaltung ist keine Kunst—Tomás Maldonados Beitrag zur Entstehung eines neuen Berufsbilds. In: Rinker D, Quijano M, Reinhardt B (eds) Ulmer Modelle-Modelle nach Ulm Hochschule für Gestaltung Ulm 1953-1968. Hatje Cantz Verlag, Ostfildern-Ruit, pp 38-49

Rittel HW (1970) Der Planungsprozess als iterativer Vorgang von Varietätserzeugung und Varietätseinschränkung. In: Jügen J (ed) Arbeitsbericht zur Planungsmethodik 4, Entwurfsmethoden in der Bauplanung. Krämer Verlag, Stuttgart, pp 17-31

Rivière $\mathrm{P}$ (2010) Der Staat als Maschine. Das Kybernetik-Experiment in Allendes Chile. Le Monde Diplomatique. https://monde-diplomatiq ue.de/artikel/!361642. Accessed 9 May 2021

Schmidt J, Funk J (2020) Project Cybersyn-Chiles kybernetischer Traum von Gerechtigkeit. Deutschlandfunk. https://www.ardau diothek.de/das-feature/chiles-kybernetischer-traum-von-gerechtigk eit-projekt-cybersyn-1-2/73914938. Accessed 9 May 2021

Schwember H (1977) Cybernetics in government: experience with new tools for management in Chile 1971-1973. In: Hartmut B (ed) Concepts and tools of computer-assisted policy analysis. Birkhäuser, Basel, Stutttgart, pp 79-138

Searle JR (1969) Speech acts. An essay in the philosophy of language. Cambridge University Press, Cambridge

Searle JR (2008) Expression and meaning: studies in the theory of speech acts. Cambridge University Press, Cambridge

Srnicek N (2016) Plattform Capitalism. Polity, Cambridge

Winograd T (1979) Beyond programming languages. Commun ACM 22(7):391-401 
Winograd T (1987) A language/action perspective on the design of cooperative work. Hum Comput Interact 3(1):3-30

Winograd T (1997) The design of interaction. In: Denning PJ, Metcalfe RM (eds) Beyond calculation. The next fifty-years of computing. Springer-Verlag, New York, pp 149-162

Winograd T, Flores F (1987) Understanding computers and cognition: a new foundation for design. Addison-Wesley, Boston
Publisher's Note Springer Nature remains neutral with regard to jurisdictional claims in published maps and institutional affiliations. 